\title{
The California Land Contract
}

\author{
John R. Hetland*
}

I

\section{INTRODUCTION}

EGAL LABELS sometimes have significant meaning, sometimes mean nothLing, sometimes mean too much. "Contract," for example, is easily understandable as a broad reference, but to grasp the vague connotations of "contract" is not to understand the subject. Similarly, "land contract" is useful as a reference to all of the agreements that relate to the purchase and sale of real property. But an understanding of the general reference is not an understanding of the elements of real property security or of real property marketing that fall within it. Much of the deceptive complexity of the law relating to "land contract" flows from the fact that significant differences between various kinds of land contracts are masked behind a common name.

A "land contract" often is a security device in lieu of a mortgage or deed of trust. To the extent this is the meaning of "land contract," security remedies may be appropriate; perhaps the judicial sale, redemption period and deficiency judgment prohibition should replace the traditional action for specific performance or for damages. But a "land contract" also is an earnest money contract, or a deposit receipt, or occasionally mutual escrow instructions; in other words, it is often the basic buy-sell agreement rather than a security device. And if this is what "land contract" means, the security debtor's protections should not interfere with the vendor's action for damages, his retention of hquidated damages, or his action for specific performance.

So, obyiously, one cannot analyze the remedial aspects of a "land contract." The purpose of the contract as a marketing instrument ${ }^{1}$ or as a security device ${ }^{2}$ is of paramount importance in determining the applicability of any particular remedy. But, surprisingly, the California courts, in developing new remedies and prohibiting old ones seem to have hypothe-

* Acting Associate Professor of Law, University of California School of Law, Berkeley.

1 Deposit receipt, earnest money contract, inutual escrow instructions, and so forth-any contract intended by the parties to be the basic buy-sell agreement as opposed to a reservation of title for security. The California Real Estate Association "Deposit Receipt," when used solely for nonsecurity purposes, is illustrative.

2 Normally the installment land contract or contract for deed-any agreement under which the seller retains title primarily as security for the price, as opposed to the initial phase of an otherwise financed purchase. Illustrative of a typical form is the California Real Estate Association "Agreement of Sale." 
sized that a land contract is a land contract-any contract that somehow relates to the purchase and sale of real property is subjected to all of the remedies or prohibitions that have been applied to any other "land contract."

In part, the purpose of this article is to carry the present approach to its ultimate conclusion-to apply the security approach of the present "land contract" cases to the marketing instrument in the few remaining areas where the California courts have not already done so. The results, as will be seen, are incredible. Yet this is the trend, and only if the entire remedial system is reanalyzed in terms of the purpose of each contract will it be possible to channel the beneficial aspects of the California land contract reform toward the objectives that the courts apparently seek. Thus part of this article can be characterized as negative speculation, speculation upon what is the law if the present trend continues without differentiation among "land contracts."

On the other hand, part of this article is positive speculation, speculation upon what the present law must be if the principles from the decided cases are divorced from their facts and reclassified as components of the security system or as components of the marketing structure. And part of this is simply descriptive and, to that extent, perhaps useful to the practitioner interested in real estate marketing or security as a drafting rather than as a litigation problem.

Speculation necessarily includes many side-traclsing details. For continuity an abbreviated table of contents may be of aid:

I. Introduction

II. History

A. Glock to Barkis-The Vendor's Era

B. Barkis to Ward-The Vendee's Era

III. The Marketing Contract

A. The Liquidated Damages Clause

1. The Problem

2. Need for a Workable Clause

3. Around Freedman

4. The Clause

B. Vendee's Equity of Redemption

C. Vendor's Affirmative Remedies

1. Specific Performance, Damages and the Anti-Deficiency Legislation

2. Damages

D. Distinction Based upon Purpose

IV. The Security Contract

A. Vendee's Equity of Redemption

1. Statutory Right of Redemption 


\section{Restitution}

B. Vendor's Affirmative Remedies

1. Effect of Anti-Deficiency Legislation

2. Cancellation; Private Enforcement

3. Damages, Action for the Price, Specific Performance

C. Present Status of the Installment Contract as a Security Device

II

\section{HISTORY}

Any thorough discussion of land contracts has to start with Glock v. Howard $\&$ Wilson Colony $\mathrm{Co}^{3}$ and, touching upon the major cases in between, should continue through Ward v. Union Bond \& Trust Co. ${ }^{4}$ Nowhere in the major cases have the courts distinguished between the marketing instrument and the security device. Glock ${ }^{5}$ refers to Civil Code section $3307^{\circ}$ as describing the measure of damages for breach of an installment contract; Freedman v. The Rector ${ }^{7}$ rehes upon installment cases and installment reasoning in reaching an installment result under deposit receipt facts; $\operatorname{Ward}^{8}$ rehes upon Freedman and other deposit receipt cases to resolve an installment instrument problem. So in briefly ${ }^{9}$ setting forth the important cases from Glock to Ward the most meaningful approach is to take it the way it is, i.e., to assume that all land contracts are alike and then by later analysis to separate the remedies according to the purpose of the contract.

\section{A. Glock to Barkis-The Vendor's Era}

Glock v. Howard \& Wilson Colony Co. ${ }^{10}$ committed California to the proposition that in the absence of exceptional circumstances the defaulting

3 123 Cal. 1, 55 Pac. 713 (1898).

4243 F.2d 476 (9th Cir. 1957).

5 Glock v. Howard \& Wilson Colony Co., supra note 3.

6 "The detriment caused by the breach of an agreement to purchase an estate in real property, is deemed to be the excess, if any, of the amount which would have been due to the seller, under the contract, over the value of the property to him." This is the measure of damages for breach of the buy-sell or marketing agreement, but rental value rather than $C_{A C}$. CIv. CoDE $\$ 3307$ benefit of the bargain damages is appropriate in the security or installment situation, see note 125 infra, except in the case of a judicial sale of the property and here difference value is relevant only in the sense that the property's forced sale value has some connection with value at the time of sale.

T37 Cal.2d 16, 230 P.2d 629 (1951).

8 Ward v. Union Bond \& Trust Co., supra note 4.

9 Extensive discussion of what used to be is silly-the problem of what is requires considerable examination and the past is relevant only as necessary to understand the current problems. If anyone is interested, however, there are several good law review comments summarizing the cases at various early stages of development. See 18 CALIF. L. REv. 681 (1930); 27 Calir. L. Rev. 583 (1939); 37 CaLIF. I. Rev. 704 (1949); 23 SO. CaI. L. Rev. 110 (1949); 2 Stan. L. Rev. 235 (1949); 40 CaITF, L. Rev. 593 (1952).

10 Supra note 3. 
vendee forfeited the payments he had made under the contract. ${ }^{11}$ According to Glock, the vendor's choice of remedies included benefit of the bargain damages, ${ }^{12}$ specific performance, "do nothing" (retention of title and of buyer's payments), and rescission. In addition to outlining the remedial possibilities, Glock tried to clarify the status of the parties further by citing all of the statutes ${ }^{13}$ the court deemed pertinent.

Because Glock's forfeiture, if applied as an indiscriminate rule, often would be unconscionably harsh and because the court failed to cite the two statutes that apparently were intended to resolve the forfeiture problem, ${ }^{14}$ it was probably inevitable that lines of cases would develop, as they did, relieving the vendee from a forfeiture if he could show some variant of waiver, estoppel, or lack of tender..$^{15}$ But as a general rule, forfeiture remained the order of the day, ${ }^{16}$ and even Civil Code section 3275, when finally discovered, was rapidly buried under the court-conceived notion that it could not apply to a contract where payment was a condition precedent to the vendee's right to receive a deed ${ }^{17}$ or where time was of the essence, ${ }^{18}$ both of which requirements have long been, and remain today, "boiler-plate" in practically all contracts.

\section{B. Barkis to Ward-The Vendee's Era}

Although it survived the New Deal virtually untouched, ${ }^{10}$ the seller's golden age ended in California in 1949 with the simple holding in Barkis

11 Factually, Glock probably was not a forfeiture case. The vendee had paid only a small amount and had been in default a considerable period of time. It is likely that the result of the case would be the same today, but for a different reason, viz., the vendee could not prove the amount paid to be more than the vendor's damages.

12 Pursuant to CAI. Crv. CODE $\$ 3307$, an improper measure under an installment contract. See note 6 suppra.

13 Cat. CTv. CoDE $\S \S 3306,3307$ (measure of damages), 1660, 1671 (liquidated damages), 3384, 3387, 3389 (specific performance).

14 CAT. Crv. CODE $\$ 3275$, "Whenever, by the terms of an obligation, a party thereto incurs a forfeiture, or a loss in the nature of a forfeiture, by reason of his failure to comply with its provisions, lie may be relieved therefrom, upon making full compensation to the other party, except in case of a grossly neghigent, willfnl, or fraudulent breach of duty." CAL. Crv. CODE $\$ 3369$, "Neither specific nor preventive relief can be granted to enforce a penalty or forfeiture in any case ...."

15 See, e.g., Boone v. Templeman, 158 Cal. 290, 110 Pac. 947 (1910) ; McDonald v. Kingsbury, 16 Cal. App. 244, 116 Pac. 380 (1911).

$16 \mathrm{Viz}$., the vendor's title would be quieted without restitution to the vendee, or the vendee's prayer for specific performance would be denied. See, e.g., Oursler v. Thacher, $152 \mathrm{Cal}$. 739, 93 Pac. 1007 (1908); Schwerin Estate Realty Co. v. Slye, 173 Cal. 170, 159 Pac. 420 (1916); Pitt v. Mallalieu, 85 Cal. App. 2d 77, 192 P.2d 24 (1948).

17 Ebbert v. Mercantile Trust Co., 213 Cal. 496, 2 P.2d 776 (1931).

18 Collins v. Eksoozian, 61 Cal. App. 184, 214 Pac. 670 (1923); Henck v. Lake Hemet Water Co., 9 Cal. 2d 136, 69 P.2d 849 (1937).

${ }^{10}$ See Comment, 27 CaIrF. L. Rev. 583 (1939) listing the vendor's remedies-a list that was accurate in 1939 and remained accurate until 1949. Cax. Code Crv. Proc. \&580b was 
ข. Scott ${ }^{20}$ that Civil Code section $3275^{21}$ was itself sufficient to preclude a forfeiture, ${ }^{22}$ even though the time of the essence clause was not waived and even though the vendor was not estopped to assert it. Thus, Barkis was the beginning of the end of the installment land contract. It need not have been, because all that Barkis really did was to apply section 3275 literally, thereby cleansing the land contract system of a lot of technical nonsense and leaving it workable and relatively fair. Because the court relied on section 3275 , only the nonwillful defaulter was protected and he only to the extent that he could be without damaging the innocent seller.

But it was not long before a willfully defaulting vendee sought similar protection. Because section 3275 expressly does not apply to a willful default, the willfully defaulting plaintiff in Baffa v. Johnson ${ }^{23}$ argued that if the seller sued him, the seller could recover only benefit of the bargain damages, not the amount fortuitously paid by the buyer. And if the seller sought to quiet title or sought other affirmatve relief, he would have to make restitution as a prerequisite. ${ }^{21}$ Thus, argued plaintiff, the seller should be compelled to make restitution in a direct action by the buyer. He lost. It was not that he had failed to convince the court, but somewhere in the rush of things he had failed to prove that the seller's damages were less than the amount the seller retained.

Shortly thereafter a willfully defaulting buyer did get his money back in Freedman v. The Rector. ${ }^{25}$ Freedman was, factually, a deposit receipt case, while Barkis was an installment contract case. In neither did the court indicate that the purpose of the contract could in any way affect the relief. If one were to read the Freedman opinion apart from its facts, he would have little question but that Freedman related to the security device problem. ${ }^{26}$ Regardless of the kind of instrument to which it was intended to

amended to prohibit a deficiency judgment under a land contract in 1935, but this did not reach the forfeiture problein and really had bitle effect on any of the vendor's remedies until 1953 when the court redefined "deficiency judgment" in Brown v. Jensen, 41 Cal. 2d 193, 259 P.2d 425 (1953).

2034 Cal. 2d 116, 208 P.2d 367 (1949).

21 Supra note 14.

22 I.e., to prohibit the quieting of the vendor's title where the vendee sought to reinstate the contract.

2335 Cal. 2d 36, 216 P.2d 13 (1950).

24. This is the result dictated by CAL. Crv. CoDE $\$ 3369$, sespra note 14 .

2537 Cal. 2d 16, 230 P.2d 629 (1951).

20 "A penalty equal to the net benefits conferred by part performance . . . not only fails to take into consideration the degree of culpability, but its severity increases as the seriousness of the breach decreases . . . . The rule contended for by respondent, carried to its logical sequence, would forfeit every dollar paid by appellant and still leave respondent in possession of the land even if appellants had paid the last instalment but one, and then defaulted. In answer to this, it unay be said that such is not the case at bar. But where are we going to draw the line?' (Malmberg v. Baugh, 62 Utah 331, 340, 345)... ." Freedman v. The Rector, 37 Cal. 2d 16, 22, 230 P.2d 629, 632 (1951). 
relate, Freedman, of course, was an extension of the vendee's protection beyond that given him by statute. The vendee's relief was said to be based upon the general policy of the law against forfeitures.

But if this is the reason the court returned the willfully defaulting vendee's payment, ${ }^{27}$ it probably follows, reasoning from the same general policy against forfeitures, that any other relief that accomplishes the sanie purpose is equally available. So why not give the purchaser the right to compel specific performance of the contract he has willfully breached?

The Ninth Circuit did. In Ward v. Union Bond \& Trust $\mathrm{Co}^{28}$ the vendee under an installment contract willfully defaulted after paying a considerable portion of the price. The vendor gave the vendee sixty days to cure the default as called for in their contract and, upon the expiration of the sixty days, presumably would have attempted to retake possession and retain payments as provided by the contract. Eight days after the sixty day period had elapsed, the vendee brought an action to have the contract declared to be in force and for specific performance. The vendor cross complained for damages, admitting the vendee's right to restitution if his payments exceeded damages, and for a decree quieting its titke. Thus, the court was faced with the next step, i.e., whether a willfully defaulting vendee may refuse restitution and insist, instead, upon specific performance. In predicting that he could under California law, the court concluded, correctly it seems, though perhaps unfortunately, that the California land contract reform will continue until the equation of the land contract and mortgage is complete.

The federal court based its conclusion primarily upon its interpretation of the recent California cases, its interpretation being that fault is irrelevant, that each party should be placed in a position to enjoy the benefit of the bargain and that each party should avoid any loss. There are indications that the federal court correctly analyzed the Califorma position. In Barkis, for example, the court said a vendee is better off when he seeks specific performance than he is when he seeks restitution because he avoids the difficult task of proving that the vendor's damage exceeded the vendee's loss-in other words, he avoids having to prove a forfeiture. ${ }^{20}$ And the

${ }^{27}$ To the extent the payment exceeded the vendor's actual damages.

28243 F.2d 476 (9th Cir. 1957).

29 Since Barkis was based on CAL. Crv. Code $\$ 3275$ which requires at least prospective forfeiture, seemingly the vendee's burden of proof sbould be the same, i.c., he should be forced to prove that the vendor's damages are less than the amount he vill retain if the contract is terminated. Evidently the current interpretation of $\$ 3275$ is that forfeiture in the comparison sense is irrelevant. See, e.g., Barkis v. Scott, 34 Cal. 2d 36, 216 P.2d 367 (1949); Ward v. Union Bond \& Trust Co., 243 F.2d 476 (9th Cir. 1957); Scarbery v. Bill Patch Land \& Water Co., 184 A.C.A. 89, 110, 7 Cal. Rptr. 408, 420 (1960). Not all of the appellate courts are in accord, however. See Cupps v. Hendricks, 137 Cal. App.2d 211, 289 P.2d 810 (1955), requiring the trial court to make a finding on unjust enrichment in the willful clefault situation. 
court in Freedman intimated that the vendee could have had specific performance had he not expressly "rescinded" (actually repudiated) the contract.

If reinstatement is the preferred remedy under section 3275 because of the difficulty the nonwillfully breaching vendee might otherwise have in proving the amount to be refunded, it is probably the willful defaulter's preferred remedy in the "beyond Civil Code section $3275^{\prime 30}$ area for the same reason. It was this type of approach ${ }^{31}$ that was in a large part responsible for the result in Freedman. On the other hand Baffa v. Johnson inferred, though it was really only the plaintiff's argument, that fault is relevant when a party seeks to reinstate because he must then proceed under section 3275; it is only in the "beyond Civil Code section 3275" area where fault is irrelevant and there relief, apparently, is limited to a refund. ${ }^{92} \mathrm{Be}$ this as it nay, the support of the appellate branch cases ${ }^{33}$ coupled with the Barkis-Freedman comparison would probably lead any federal court attempting to predict California law to Ward's result.

Deferring the impact of these cases until it is in context and assuming, as it seems prudent to do until the California court rules otherwise, that Ward represents California law, it is nevertheless apparent even from a limited discussion of the cases that fault, both in the marketing and in the security context, is no longer relevant. In the abstract it is appealing to forget fault and award damages solely as compensation..$^{34}$ But the abstract leaves out the "people" problems-it overlooks the installment purchaser who continually defaults and then reinstates, as he may now do, just to harass and "cash out" at a discount or to accelerate the nonaccelerable instrument; it also overlooks the purchaser under a deposit receipt who willfully breaches, sees a profitable resale by the vendor and clouds title by notice of lis pendens at the beginning of his action for specific perfornuance

${ }^{30}$ I.e., in the area where the willful defaulter can get restitution based upon the policy against forfeitures notwithstanding lack of statutory aid.

31 In the context of 'if the vendor seeks affirmative relief lie must make restitution, thus if the vendee sues the result (restitution) must be the same.'

32 A direct holding to this effect which is, incidentally, also the English rule, is Crofoot v. Weger, 109 Cal. App. 2d 839, 241 P.2d 1017 (1952).

33 See, e.g., Nelson v. Dangerfield, 125 Cal. App. 2d 146, 269 P.2d 953 (1954). In Petersen v. Ridenour, $135 \mathrm{Cal}$. App. 2d 720, 287 P.2d 848 (1955) the court indicated that every vendee has an equity of redemption, i.e., he can reinstate and perform the contract, but factually the case dealt with a nonwillful defaulter who had the most compelling of equities. See 3 U.C.I.A. L. REv. 264 (1956). Contra, Crofoot v. Weger, supra note 32. Another approach is that of Scarbery v. Bill Patch Land \& Water Co., suprc note 29, where the court sustained the trial court's finding of nonwillfulness on evidence so overwhelmingly thin (i.e., in the face of clear evidence that the breach was willful) that the qualification is essentially read out of 83275 .

34 "For this by nature is equitable, that no one be made richer through another's loss." Pomponius, as quoted by Nordstrom and Woodland, Recovery by Building Contractor in Default, 20 O\#по ST. L.J. 193 (1960). 
of the contract he has breached, lifting the notice only upon receiving a share of the profit. In order to determine what the law is in the areas not yet reached by the court it is necessary to put people back in the picture. And it is ineaningful to examine the problems only by treating the marketing contract separately from the security contract, as the California courts ultimately will have to.

\section{III}

THE MARKETING CONTRACT

\section{A. The Liquidated Damages Clause}

\section{The Problem}

According to Civil Code section 1671, "the parties to a contract may agree therein upon an amount which shall be presumed to be the aniount of damage sustained by a breach thereof, when, from the nature of the case, it would be impracticable or extremely difficult to fix the actual damage."

In Freedman v. The Rector ${ }^{35}$ the buyer agreed to pay $\$ 18,000$ for the property involved, gave a $\$ 2,000$ deposit, then unjustifiably repudiated the contract and demanded the return of his $\$ 2,000$ deposit. Because the seller shortly thereafter resold the property for $\$ 20,000$ and thus suffered no actual damage, the court ordered the return of that part of the buyer's $\$ 2,000$ that exceeded the seller's expenses of the first sale, saying, "Although such a provision [retention of down payment by vendor] ... is presumptively valid, if the down payment is reasonable in amount ... when as in this case, the evidence establishes that it would not 'be impracticable or extremely difficult to fix the actual damages' ... such a provision may not be enforced as one for liquidated damages."36

The court conld not have meant what it seemed to say. "Presumptively valid" and "evidence in this case establishes" do not belong in the same sentence. If the validity of a hiquidated damages clause under section 1671 depends upon the evidence in the case showing actual damages with little difficulty, then each case must be litigated to determine, through hindsight, whether or not the actual damages can be fixed and how much they are. And regardless of the final result the parties have had to litigate actual damages, the avoidance of which, presumably, was a major reason for using a liquidated damages clause in the first place. Under a pessimistic reading of Freedman, either the court means damages "in this case" are not extremely difficult to fix because the vendor subsequently sold at a profit or it means that the damages are never "extremely difficult" in a deposit receipt land contract case because Civil Code section 3307 provides a ready

35 Supra note 7.

3637 Cal. 2d 16, 23, 230 P.2d 629, 633 (195I). 
measure of damages. ${ }^{37}$ Either alternative leads to the same result. Even without a subsequent resale the parties could, with or without expert testimony, prove the value on the date of the breach and thus no case would be within section 1671. So never, except in the case where actual damage roughly equates the liquidated damages as shown by subsequent events, could there be a good liquidated damages clause-but then it is really a judgment for actual damages anyway, the parties having had to show damages rather than their anticipated difficulty in proving them.

But to look back at the time of trial and consider whether or not it turned out to be too difficult to ascertain damages in light of what happened at and after the breach is not what section 1671 contemplates. The usual approach is to consider whether, at the time the contract was made, it appeared that damages would later be difficult to ascertain, ${ }^{38}$ and this limits the evidence to whether or not it would so appear to the parties at the time of the contract, regardless of how it appears in view of subsequent developments. Surprisingly, though, the Cahifornia Supreme Court has gone even further than the traditional approach in finding prospective impracticality. In two cases, ${ }^{39}$ both of which were filed February 6,1953 , and neither of which mentioned Freedman, the supreme court enforced the liquidated damages clause because it appeared that at the time of the contract it would not have been practicable or reasonably possible to fix the probable damage resulting from breach. Thus, section 1671 was interpreted not only to require the court to look at the situation in light of the facts known at the time of the contract, but also to look only to the difficulty or inipracticality of predicting an actual amount of damages at that time rather than to the then apparent difficulty the parties could expect in ascertaining actual damages after the event. In both cases moreover the actual damages were probably a definite amount and easily ascertainable. ${ }^{40}$

This approach would sustain a liquidated damages clause in practically every case, at least with respect to section 1671 requirements, because rarely will the parties know with any certainty just what damages a breach will entail, market conditions, tine of breach, other commitments of the

37 This was the approach in Drew v. Pedlar, $87 \mathrm{Cal}$. 443, 25 Pac. 749 (1891) and was suggested as still the law in 1921 by Arndt, Liquidated Damages in Californic, 10 CArTr. L. REv. 8 (1921). Arndt was late, though; the approach was discredited hy Glock v. Howard \& Wilson Colony Co., supra note 3 and never again used-unless the court intenced to revive it in Freedman which is unlikely in view of the "presumptively valid" language.

38 See, e.g., 5 Corbin, Contracts $\& 1060$ at 294 (1951); Dunbar, Drafting the Liquidated Damage Clatse-When and How, 20 OHro St. L.J. 221 (1960); 3 Wrictston, Contracts $\$ 683$ at 2201 (2d ed. 1936) ; Comment, 5 Stan. L. Rev. 822 (1953); Note, 27 So. CaL. L. Rev. 209 (1954).

30 Atkinson v. Pacific Fire Extinguisher Co., 40 Cal. 2d 192, 253 P.2d 18 (1953); Better Food Markets, Inc. v. American Dist. Tel. Co., 40 Cal. 2d 179, 253 P.2d 10 (1953).

40 Caveat: These cases, factually, involved a disclaimer or limitation of liability, but they were treated as though they involved a liquidated damages clause and the opinions are solely liquidated damage opinions. 
parties, and so forth, being infinitely variable. Possibly the court was concerned with the requirement that the amount of liquidated damage be a reasonable estimate by the parties of actual damages and read this requirement into section 1671's test. But even if the court backs off somewhat and holds that section 1671 really relates to apparent impracticality in later fixing actual dainages rather than in impracticality in prospectively predicting the amount of actual damages, the clear holding that "the court should place itself in the position of the parties at the tinie the contract was made ...." indicates that the court had something else in mind with its earlier Freedman approach. "It is the look forward, and not backward, that we are ealled upon to take.' This rule is too well settled to admit of further discussion."

Still, the vendor in Freedman had to return part of the deposit.

\section{Need for a Workable Clause}

But if the defendant in Freedman resold at a profit anyway, why worry about his extra "pound of flesh?" Putting "people" back into the picture helps to answer the question and perhaps helps to demonstrate that the court chose an earnest money case to correct an abuse under a security instrument.

Let us use Freedman's figures and supply what could often be the background facts, not Freedman's facts, but not uncomon facts either. By August 1 , the seller, let's call him. Shylock — the court does ${ }^{43}$ - has had his house shown by various nembers of a nultiple listing service at $\$ 24,500$. He had previously turned down an offer of $\$ 22,000$, but upon the August 1 expiration of the broker's listing he was offering the house at $\$ 23,000$, there no longer being a commission involved. He was selling because he had taken a job in Florida; he had to be there by September 1 and it was important to him to move his family and get his children started in school. He already (1953).

41 Better Food Markets, Inc. v. American Dist. Tel. Co., 40 Cal. 2d 179, 185, 253 P.2d 10, 14

42 "Although the law will not assist in the vivisection of the victim, it will often permit the creditor to keep his pound of flesh if he can carve it for himself." Freedman v. The Rector, 37 Cal. 2d 16, 21, 230 P.2d 629, 632 (1951), quoting from Ballantine, Forfeiture for Breach of Contract, 5 MnNo. L. Rev. 329, 341 (1921). Notice, incidentally, that even this statement, as shown by its reference to debtor and creditor rather than to buyer and seller related to the parties to the security contract, not the earnest money contract.

43 The court in Freedman called the creditor a vivisectionist, supra note 42 , and referred to the law as Pontius Pilate (washing its hands of the whole affair) in an earlier part of its quote from Ballantine. It is Ballantine, supra note 42, who calls him Sbylock, 5 MrNv. L. REv. 329, 347 (1921). Calling the law Pontius Pilate suggests names for the debtor and creditor but they seem quite mappropriate, so I chose to take the rest of Ballantine, call the creditor "Shylock," and pin this on the court, too-it is in the same vem. Clearly, however, this is an unfair inference froin the court's use of the quote. The use of "Shylock" is, admittedly, exaggerating the court's position. 
had earnest money on a house in Florida. It was an excellent buy, but his purchase contract was contingent upon selling his California house by September 1, so monetary loss in the out-of-pocket sense was not involved.

Against this background, a buyer - call him DeFault to distinguish him from a later buyer-offered him $\$ 18,000$ on a deposit receipt contract dated August 1 . Shylock countered; DeFault sat tight at $\$ 18,000$ but finally agreed to raise his deposit from his initial $\$ 500$ to $\$ 2,000$ and to remove a financing contingency upon Shylock's insistence that if Default should back out, Shylock should have something to cover his loss on the realistic leisurely sale value. Closing was set for August 29 and time was made of the essence.

On August 15 DeFault's wife saw the house for the first time and did not care if it was a steal, she simply would not live there. So DeFault defaulted and demanded his money back. Shylock could have sued for specific performance, but this contract was attractive to him only if he could have closed in time to complete his Florida purchase by September 1 . The same time factor coupled with the fact that he would not have had any damages under Civil Code section 3307 anyway, the property being worth more than the contract price at the time of breach, was the answer to an action for damages.

Shylock was "stuck." He had lost his Florida bargain, he and his family could not move together, his children had to change schools in the middle of the year, and all he had to show for it was DeFault's $\$ 2,000$-so far. Without the time factor pressing him, Shylock went back on the market at a realistic $\$ 23,500$, listing again with a broker. On August 25 the broker brought him an offer for $\$ 21,200$, leaving $\$ 20,000$ net to Shylock after commission. He accepted, the deal was closed on September 30, and DeFault sued for restitution.

DeFault, according to Freedman, has the burden of proving that Shylock's damages are less than the amount retained. That's easy. He can show the contract price and the higher resale within a short time. His realtor would testify that the property was worth more than $\$ 18,000$ at the time of breach and Shylock would admit the same fact on cross-examination. He can also bring out that Shylock had no commission to pay and that there vere no expenses connected with the sale. He would have shown thereby the facts of Freedman.

Then it would be Shylock's turn. He could try to explain about the children in school, the difficulties involved in finding a new house in Florida, that the house he finally bought in Florida was not as good but cost a lot more, and that his low price to DeFault was a "hurry" price. But will the courts listen, or are they inclimed to say- "Talk about money, Shylockwhat did you lose?" 
Suppose the court would be sufficiently impressed with the possibility that loss of the Florida bargain was a foreseeable consequential loss to let Shylock really show how good it was-where is the real burden of proof? Shylock could bring in a Florida expert or two to tall about value, but there is only $\$ 2,000$ at stake and experts are just more than he can afford.

Finally, Shylock might try to say something to the effect that these were the very things DeFault and he had in mind when they considered the amount of the "forfeiture." But he cannot dispute that the evidence in his case shows that damages "would not be impracticable or extremely difficult to fix ...." "44 And, undoubtedly, if "damages" mean actual damages, and if "evidence in this case" means the clause should be considered in retrospect, they are not.

Admittedly, one will not find Shylock's facts often in the cases. But the reason is not that some variation is not typical, but instead that these facts are generally irrelevant. Time makes it worth minus $X$ dollars to sell for reasons legally irrelevant but extremely relevant to the parties at the time the contract is made. Penalties and forfeitures are prohibited because they are unconsionable. But if the law is going to interfere with the freedom to contract for liquidated damages (or even a forfeiture in the dollar sense) based upon the justice of the thing, it must at least decide where justice is by considering all of the factors of the equation. One can argue that damages of any kind based upon Shylock's evidence would be compensating for "pain and suffering" resulting from breach of a contract. And perhaps it is. The parties made a contract using a "forfeiture" clause with that in mind. If the courts say they cannot use it, then do they not have to say they will look at the factors that impelled its use in deciding whether or not it is unconscionable? Perhaps money must be the only common denominator and certainly it must be the only manner of expressing damages. But this brings us right back to Freedman-is it really true that it is not difficult or impractical to measure damages in a typical deposit receipt case regardless of resale appearances?

Considering only the dollar amounts, it is easy to detect a penalty. But there are reasons for overlooking dollars and supporting the parties' use of the liquidated damages clause. Shylock's unprovable loss is only part of it. Avoiding the expense of trial, avoiding the expense of expert witnesses to prove value, taking away the club of a litigious vendee who knows that his threatened lawsuit is potentially dangerous enough to "nuisance out" a settlement, ${ }^{45}$ saving the developer from depressing the value of the rest of

44 Supra note 36.

45 Litigation of the occasional abuse where the amount chosen is, prospectively, far in excess of any reasonable expectation of damages is a far different matter than potential litigation over every deposit simply because the value of the property has not dropped. 
his tract by proving resale at a loss to be resale at true value ${ }^{16}$ - these, too, have some bearing on the problem.

Granting that the defaulting vendee should be allowed to test whether or not the amount involved is so disproportionate to the amount that could reasonably have been expected by the parties to be potential damage that it qualifies as a penalty, ${ }^{47}$ the desirability of a workable clause demonstrates that the issue should be put back in the "prospective" context so that the liquidated damages clause is in fact, as the Freedman court said, "presumptively valid."

\section{Around Freedman}

Assuming the desirability of a liquidated damages clause in the marketing contract, the problem of avoiding Freedman apparently remaius. But the problem is only apparent, not real. Freedman's hiquidated damages language was dicta ${ }^{48}$ - but of greater importance, it was dicta aimed at the installment contract and the court simply did not intend to comment upon liquidated damages under a deposit receipt or earnest money contract.

All of Freedman's arguments are installment arguments; the abuses it seeks to avoid are security device abuses; its authorities are security device authorities; ${ }^{49}$ it was, in short, an installment land contract case with deposit receipt facts. This, perhaps, explains Freedman's definition of "unjust enrichment" to the vendor and "penalty" to the vendee, i.e., any amount in excess of the vendor's actual damage. This, too, is the installment device argument.

To have an enforceable liquidated damages clause, the proponent must show that at the time of making the contract it appeared to be impractical or extremely difficult to fix actual damages ${ }^{50}$ and he must show that the amount selected bears some reasonable relation to probable actual loss. ${ }^{5 x}$ The second ingredient, however, is not a matter of looking back to see what

16 This reason seems to have motivated a New York legislative commission in recommending a percentage liquidated damage clause. See Note, 52 Harv. L. REv. 129 (1938).

47 See 5 Corbin, Contracts $\$ 1059$ at 291 (1951).

48 The deposit receipt in Freedman did not make liquidated damages the sole money remedy of the seller. Thus the clause was not a true liquidated damages clause and the discussion of liquidated damages was totally unnecessary. See, e.g., McCarthy v. Tally, 46 Cal.2d 577, 297 P.2d 981 (1956); Atkinson v. Pacific Fire Extinguisher Co., 40 Cal. 2d 192, 253 P.2d 18 (1953); Better Food Markets, Inc. v. American Dist. Tel. Co., 40 Cal. 2d 179, 253 P.2d 10 (1953).

40 Some of which, e.g., Corbin, The Right of a Defaulting Vendee to the Restitution of Installments Paid, 40 YALE L.J. 1013, 1030-31 (1931) themselves find liquidated danages proper in the earnest money contract, though invalid, if based on payments made in the installment contract.

50 Cas. Crv. Code $\$ 1671$; Stark v. Sbemada, 187 Cal. 785, 204 Pac. 214 (1922) ; RestateIIENT, CoNTracts $\$ 339$ (1932); 5 CoRBIN, Contracts $\$ \$ 1059$, 1060 (1951). This requirement, as demonstrated earlier, is normally present in the marketing context.

61 Dyer Bros. v. Central Iron Works, 182 Cal. 588, 189 Pac. 445 (1920); Rice v. Schmid, 18 Cal. 2d 382, 115 P.2d 498 (1941); 5 CoRbn, Contracts $\$ 1063$ (1951). 
the damages actually were, but is instead a matter of determining whether or not the parties adopted a reasonable formula for selecting, or otherwise made a reasonable attempt to select, an amount. ${ }^{52}$ If the formula or approach is proper, the court should not compare the amount selected with actual damage; ${ }^{53}$ but if the method used by the parties does not represent a legitimate attempt to anticipate probable actual loss, the court should look to the amounts involved to determine the penalty question. ${ }^{54}$

There seems little question that the usual installment contract formula, forfeiture of all payments made, simply is not an adequate attempt by the parties to forecast something akin to possible damages. So in the installment cases, the first step, determination of whether or not the parties have used a reasonable method of determining amount, need not even be considered in the usual (forfeiture of payments) case and the court is justified in looking immediately to the penalty question in deciding the case based upon actual damages. This was the Freedman approach, and this is why the Freedman approach is the installment contract approach; it omits the first step, as it should in most imstallment contract cases, viz., it omits the initial determination of reasonableness.

Since a California court may enforce a liquidated dannages clause in a marketing contract, the court's approach presumably will be to treat each part of the question in its proper order. Thus the court should first decide whether at the time the contract was made the parties were justified in thinking damages might be impracticable or difficult to ascertain. If it should appear that they were, the issue no longer is whether the vendor is getting more than actual damages but ouly whether or not at the time of the contract the parties chose an amount, or a formula likely to lead to an amount, that represented a reasonable endeavor to estimate fair compensation for any loss that might be sustained. " $[\mathrm{I}] \mathrm{t}$ is clear that the actual loss resulting from a breach could in many cases be less than the amount provided for. It is equally clear that in many other cases the actual loss would exceed that amount."

\section{The Clause}

At the contract drafting stage there are several things that could be done to improve the vendor's position under the clause. There are, perhaps, more devices which can substantially impair it. The suggestion was once

62 See, generally, Comments, 5 StaN. L. REv. 822 (1953), 27 So. CAL. L. REv. 209 (1954); Dunbar, Draftirg the Liquidated Damage Clause-When and How, 20 Omo Sr. L.J. 221 (1960).

53 See, e.g., Atkinson v. Pacific Fire Extinguisher Co., 40 Cal. 2d 192, 253 P.2d 18 (1953); Better Food Markets, Inc. v. American Dist. Tel Co., 40 Cal. 2d 179, 253 F.2d 10 (1953), where the amount missed actual damage by several thousand times.

64 See note 52 supra.

65 Better Food Markets, Inc. v. American Dist. Tel. Co., 40 Cal. 2d 179, 187, 253 P.2d 10, 15 (1953). 
made, for example, that an express waiver of Civil Code section 3275 might be enforceable. ${ }^{56}$ Overlooking issues such as whether or not section 3275 is a matter of public policy, ${ }^{57}$ the short answer is that the court has consistently refused to enforce an agreement suggesting a forfeiture and an express waiver adds nothing to an express agreement. And, of course, the liquidated damages-forfeiture problem now has gone far beyond the nonwillful plaintiff of section 3275 .

Another common approach which seems more detrimental than beneficial is to phrase the contract in terms of an option and thus avoid the liquidated damages clause. ${ }^{58}$ If the suggestion contemplates a bona fide change in the customary real estate marketing structure so that a prospective residential purchaser would actually purchase an option pending determination of marketability of title, termite inspection, financing possibilities, and so forth, it would probably avoid the forfeiture problem. ${ }^{59}$ But how much would the average purchaser pay for a bona fide option? Assuming he actually purchases an option and has received full value even though his decision not to exercise it was based upon failure of one of the normal contingencies, it is difficult to imagine he will be willing to pay much for it. Even if the option is made contingent upon these things, and the buyer's problem solved, it would be surprising to find the normal residential seller willing to take his property off the market for long on the strength of an option rather than a binding agreement to purchase. And it seems unlikely that realtors would encourage a marketing device that generally would produce a lower fund out of which the realtor could claim his commission if the sale were not closed. ${ }^{80}$

If, on the other hand, the buyer is hable for damages upon his refusal to perform except for items expressly made contingent, the agreement is no longer an option, but is again the same old deposit receipt or earnest money contract dressed up in different language. If the option suggestion

56 Note, 37 CAITF. L. Rev. 498 (1949).

67 And thus not waivable under CAL. Crv. CoDE $§ 3513$.

58 See, e.g., Krueger, Forfeiture of Paymenis Under a Land Purchase Contract, 30 Los ANgeres B. BuLL. 377 (1955). This form seems to have been used by the parties in Lawrence v. Settle, 182 A.C.A. 447, 6 Cal. Rptr. 49 (1960), and even the Cahfornia Real Estate Association standard form seems to have been drawn with the possibility of this interpretation in the mind of the draftsman.

59 An instrument appearing to be a true option is sometimes used, Lawrence v. Settle, suspra note 58, but given a sufficiently large initial payment, the court is likely to find a forfeiture even witb the true option form. Scarbery v. Bill Patch Land \& Water Co., 184 A.C.A. 89, 7 Cal. Rptr. 408 (1960).

60 Under most listing agreements in current use the realtor earns his commission at the deposit receipt stage, often one-half of the deposit, even if the sale is not closed. See, e.g., Zerin, The Real Estate Broker's Commission, in Lead Aspects of REal Estate Transactions 39-63 (1956). Notice, too, the facts of Freedman; even though the seller returned what was left of the deposit the realtor's commission came out first. 
contemplates that the deposit receipt be made to look like an option when in fact it is not, the result of litigating it seems obvious. Thus, it is surprising to find a watered down form of this suggestion in the California Real Estate Association standard form "deposit receipt." The "forfeiture" clause of the form reads: "If Buyer fails to pay the balance of said purchase price, or to complete said purchase as herein provided, the amounts paid hereon may be retained by Seller at this option as consideration for the execution of this agreement by Seller." But usually the buyer does not pay the seller an amount as consideration for the execution of the agreement; he makes a down payment on the property in question, and to the extent the seller keeps it, he keeps it as a forfeiture ${ }^{61}$ and not as consideration for the execution of the agreement.

Taken literally, the Real Estate Association form with its pseudo option requires the buyer to forfeit his deposit "as consideration" for the agreement even if the sale is not closed because of the failure of an express contingency. ${ }^{62}$ It was inevitable, perhaps, that someone would try to take it literally and keep the deposit when the failure of an express contingency prevented the closing. The supreme court, of course, recognized that the consideration for the bilateral agreement was the mutual promises of the parties and that the deposit was part performance of the buyer's obligation, not consideration for the right to disapprove the contingencies. ${ }^{63}$

The option clause in the standard form is unlikely to excite judicial sympathy for other reasons, the major one being its total ambiguity in the hands of those dealimg with it. It provides that the seller can, at his option, keep the deposit. Does this mean his option is to keep it or to return it, as many buyers apparently believe, ${ }^{64}$ or are led to believe, ${ }^{65}$ or does it mean that the seller's option is to keep it or to elect to sue for actual damages, keeping the deposit only as a setoff against actual danages? The court has given it the latter interpretation, as it should, ${ }^{68}$ but seeningly this intended result was sufficiently hidden by the draftsman so that only the astute buyer could recognize it.

If the seller were willing to limit hinuself to liquidated damages the court probably would enforce the provision in most cases. An enforceable

61 This would not be liquidated damages because the provision under which payments were retained does not include the requirements for a hquidated damage clause. While there are cases under which the court has allowed retention as "consideration for the execution of the agreement" they are lease cases and the consideration seems to be for lolding the property off the rental market. Since it is time that is for sale under a proposed rental, the lease result probably would not affect the result of a case involving sale (rather than sale of its use) of the property.

62 Other than marketability of title which is treated differently within the form itself.

63 Rodriguez v. Barnett, 52 Cal.2d 154, 338 P.2d 907 (1959).

64 Cf., e.g., Royer v. Carter, 37 Cal. 2d 544, 233 P.2d 539 (1951).

${ }_{65}$ Cf., e.g., Fleischer v. Cosgrove, 145 Cal. App. 2d 14, 301 P.2d 911 (1956).

66 Royer v. Carter, suspra note 64. 
liquidated damages clause should be binding upon the parties and should be the limit of money damages; it should be a true liquidation of damages. ${ }^{67}$ Assuming that in most residential sale cases the seller would be willing to retain the deposit and to forego other remedies, and assuming that in most cases the buyer expects to lose his deposit if he willfully breaches, making liquidated damages the exclusive money remedy would usually be in accord with the expectation of the parties and certainly is a sine qua non of an enforceable clause. This does not inean, however, that the agreement must be an option. The contract would remain specifically enforceable, ${ }^{\text {bs }}$ but if the seller prefers money damages he would be limited to or, for that matter, enriched by, the deposit or earnest money upon which the parties have agreed.

Even a printed standard form could satisfy these requirements, assuming, of course, as would necessarily be the case, that the amount is a matter left open to be individually considered in each contract. ${ }^{6 \theta}$ Agreeing on the amount creates no new problems for the realtor or seller since present practice often includes some give and take on the amount of the deposit, and retention is generally within the contemplation of the parties. It seems then that if the form unambiguously so provided and gave the typical reasons for the use of the clause, the court would have little difficulty sustaining it. This probably was what the court meant in Freedman when it said the clause is "presumptively vahd." Evasive devices simply will not get past the court; perhaps the draftsmen should, instead, be candid.

\section{B. Vendee's Equity of Redemption}

In turming from the liquidated damages clause to other marketing problems, we should quickly finish the story of Shylock and DeFault. Although not a good story, it is a good forum for considering the danger of an unrestricted equity of redemption when applied to the marketing contract. There are, of course, several other things DeFault might have done to Shylock, most of which depend upon the applicability of Ward v. Union Bond's equity of redemption to the marketing instrument. The things that DeFault could have done to Shylock under Ward will, hopefully, prevent Ward's application to the marketing instrument when the security and marketing concepts are separated.

Since time was important to Shylock, DeFault could hurt him most by

67 See, e.g., Better Food Markets, Inc. v. American Dist. Tel. Co., supro note 48; Atkinson v. Pacific Fire Extinguisher Co., suspra note 48.

68 Cat. Crv. Code $\$ 3389$.

69 Dunbar, Drafting the Liquidated Damage Clause-When and How, 20 OHo ST. L.J. 221 (1960) suggests that the clause is never one amenable to standard form reproduction. But residential real estate sales are relatively standard, at least mechanically, and amount is the only true variable. In Better Food Markets, Inc. v. American Dist. Tel. Co., supra note 48, and Atkinson v. Pacific Fire Extinguisher Co., supra note 48, even the amount was part of a printed standard form. 
clouding his title, thus preventing a quick resale. ${ }^{70}$ It has often been suggested $^{71}$ that the customary lack of acknowledgment, which prevents recordation, ${ }^{72}$ nakes a clouded title an extremely remote risk. An imaginative vendee, however, should have little difficulty in recording his interest. Since the common provision prohibiting recordation of the contract is probably void as against public policy, ${ }^{73}$ it seems likely that the vendee could compel acknowledgment and then record. A recorded straw man assignment and reassignment, describing the original contract to keep it within the chain of title, will also accomplish the purpose. And if the contract purports to prohibit assignment, recordation of any other purported real interest, ${ }^{74}$ again describing the contract, will encumber the title. ${ }^{75}$

Even in the absence of a recordable interest, the vendee should have little difficulty clouding the title. ${ }^{76}$ Suppose, for example, the buyer, DeFault, heard about Shylock's profitable resale and wanted the profit. The right of a willfully defaulting vendee to refuse restitution, and compel specific performance ${ }^{77}$ over the objection of the vendor, gives him, in effect, an equity of redemption in the property that practically has to be foreclosed. Thus, DeFault, hearing of the pending resale, could start an action for specific performance and file a notice of lis pendens, thereby, through his equity of redemption, encumbering the title and preventing the second sale. While Freedman held that a second executed sale prevented specific performance in favor of the buyer, there is nothing to indicate that an executory deposit receipt contingent upon the seller's ability to convey marketable title would have this effect. Shylock could either settle by splitling the profit with DeFault or he could void the second contract for inability to

70 Before he could sell, Shylock would have to quiet title either by action, if DeFault was really serious, or by buying a quit claim if DeFault was mainly inclined to "squeeze" a little more.

71 See, e.g., 7 U.C.L.A.L. REv. 83, 97 (1960); 23 So. CaI. L. IREv. 110 (1949).

72 Cax. Crv. Code $\S 1170$.

73 See, Resh v. Pillsbury, 12 Cal. App. 2d 226, 55 P.2d 264 (1936).

$74 \mathrm{~A}$ bizarre example is the "Rescission of Contract and Demand for Return of Deposit and Other Costs" and "Notice of Pending Escrow" recorded (in that order) by a willfully breaching vendee in Contra Costa County Title Company v. Waloff, 184 A.C.A. 63, 7 Cal. Rptr. 358 (1960). The vendee, who apparently thought she knew a great deal of real property law from her several years of experience in law offices, knew enough to cloud the title but not enough to defend against the seller's successful slander of title action. Even DeFault, if he were inclined to cloud by recording an interest, would at least assure that the facts therein are true.

75 Generally possession will not change under the marketing instrument so possessory notice is no problem, but apparently most title companies "aware" of a forfeited contract find the title unmarketable in the absence of a quit claim, election of remedies by the vendee or a quiet title action by the vendor. Ogden, Calrfornta Real Property \$ 9:18 (1956).

${ }^{76}$ See, e.g., Cupps v. Hendricks, 137 Cal. App. 2 d 211, 289 P.2d 810 (1955).

77 Ward v. Umion Bond \& Trust Co., 243 F.2d 476 (9th Cir. 1957); Nelson v. Dangerfield, 125 Cal. App. 2d 146, 269 P.2d 953 (1954); cf. Petersen v. Ridenour, 135 Cal. App. 2d 720, 287 P.2d 848 (1955). 
furnish marketable title. Shylock's renuaining alternative, completing the second sale, would require a second buyer of amazing fortitude because Freedman probably is limited to the bona fide purchaser-and even if it is not, the second buyer probably would insist upon more than the right to a questionable lawsuit. Perhaps the equity of redemption should stay where it belongs-applicable only to the security device. Hopefully, when the instruments are distinguished, it will.

If Shylock were to forego the resale and litigate the matter, he would have several delightful alternatives. Since DeFault has clouded his title, he must at least quiet it and this means restitution of the $\$ 2,000$. For that matter, he may not get away with just restitution. If DeFault prefers specific performance, he can have $\mathrm{it}^{78}$ and can thus take advantage of any market appreciation despite his intentional default.

Suppose, instead of a resale at a profit, the market dropped so that by some three months later, notwithstanding vigorous efforts to resell, Shylock could reasonably expect only $\$ 16,000$. Surely now no one could deny him his $\$ 2,000$ "forfeiture." But suppose that DeFault does not believe it and brings his suit for restitution. Shylock undoubtedly would cross-complain for specific performance. The result could well be, as it was in a recent case, ${ }^{79}$ that Shylock will be deried specific performance, the time lag making it inequitable to so decree, but DeFault will obtain a judgment against Shylock for return of $\$ 2,000$. Neither part of the judgment, denial of specific performance where for extraneous reasons it is inequitable or restitution even in a falling market, is surprising, if considered alone. The first part is the result of a common equitable principle,$^{80}$ and the second is compelled by the Freedman case when coupled with the statutory measure of damages, viz., since the property was worth more than the $\$ 18,000$ contract price at the time of the breach, ${ }^{81}$ the vendor suffered no damage despite a later loss on resale and thus retention of the deposit is a forfeiture. ${ }^{82}$ But relying upon both in the same case is similar to betting on a horse after the race is over.

78 This assumes that Ward is applicable to the marketing instrument, an assumption which, bopefully is incorrect in order to avoid the results inentioned in the text.

79 Pasteur Realty Corp. v. LaFleur, 154 Cal. App. 2d 5, 315 P.2d 374 (1957). The result in the text does not describe the Pasteur facts, but instead the result that the Pasteur reasoning leads to. In Pasteur there was no resale but the vendor bad to return the difference between deposit and value at the time of the breach. The mequity preventing specific performance was considered at the time of trial. The action was commenced within a month of the breach and the time lag inaking specific performance mequitable seems to have been entirely the result of calendar congestion.

80 Incorporated, incidentally, into CaL. Crv. CodE $\$ 3391$.

81 Under CAL. Crv. CoDE $\$ 3307$ difference damages are computed by comparing contract price with value at the time of the breach. Royer v. Carter, 37 Cal. 2d 544, 233 P.2d 539 (1951).

82 This, incidentally, is why Shylock could not instead have been successful in a counterclaim for damages-there were none using the $\$ 330$ 7 and Royer v. Carter, supra note 81, approach. 
The difficulty is the difference in time relevant under each test. The specific perfornance decree usually would not be inequitable, notwithstanding time, if there had been no decline in market value. So value is considered as of the time of the action. On the other hand, difference in value for measuring damages is calculated only as of the time of the breach and value at the time of the action is irrelevant. Using different times to resolve that which within a single case should be the same issue is, to say the least, disquieting. Perhaps this is in part why it has been true in the past, and in most jurisdictions remains true, that the buyer may never have restitution as long as the seller remains willing and able to perform. ${ }^{83}$ When the case of a vendee seeking restitution in defiance of the vendor's continuing willingness to perform reaches the California Supreme Court, it seems reasonable to assume that the appellate branch determination of the issue ${ }^{84}$ will be discarded.

It is obvious what happens when the same case is further encumbered by Ward; the vendee's alternatives are increased to include his right to compel specific performance of the contract he has willfully breached if time should increase its value and thus prove his original breach to have been unwise. But if Ward is limited to the security instrument, where value speculation is minimal as a result of measuring damages by rental value, the law again becomes reasonable. And Shylock, who in any event is here bowing out, can go carve his pound of flesh, if that is what it really amounts to.

\section{Vendor's Affirmative Remedies}

\section{Specific Performance, Damages and the Anti-Deficiency Legislation}

Rarely will delay, ${ }^{85}$ inadequacy of consideration ${ }^{86}$ or other inequities be a factor in a vendor's action for specific performance. Given a relatively stable market with similar values at the time of sale and time of breach ${ }^{87}$ specific performance should, therefore, be a satisfactory remedy. But several problems remaim if "land contract" law is applied to the marketing instrument. The results to be described in this section are those reached under the security contract. They should not be the results under the marketing contract; but the point can best be made by illustration.

83 See, e.g., Corbin, The Right of a Defaulting Vendee to the Restitution of Installments Paid, 40 Yale L.J. 1013, 1017-18 (1931); Restatesacent, Contracts $\$ 357$ (1932).

84 By Pasteur Realty v. LaFleur, supra note 79.

85 E.g., Pasteur Realty v. LaFleur, supra note 79; CAL. Crv. CODE $\$ 3391$.

${ }^{88}$ CAI. Crv. Code 83391 ; Ehrhart v. Mahoney, 170 Cal. 148, 148 Pac. 943 (1915) ; Gilbert v. Mercer, 179 A.C.A. 28, 3 Cal. Rptr. 456 (1960) (here inadequacy of consideration was the basis of the denial of specific performance and apparently failure to establish claim for specific performance was the basis for denying damages).

87 Thus, no benefit of the bargain damages. 
The problem begins with the form of the decree. Ideally, it would give the vendor a judgment for the price and continue the case in the court's jurisdiction to assure that the vendee obtains title when the vendor recovers the price- the court would be more or less of an escrow agent. At least two appellate cases have adopted this form. ${ }^{88}$ It is questionable, though, whether the supreme court would follow suit, because traditionally it has held that the court cannot compel an unwilling or unable vendee to pay the price. ${ }^{89}$ Instead, the result of the vendor's suit for the balance of the purchase price or for specific performance is a decree in the alternative, providing that if the vendee will not accept the conveyance and pay the price, the property will be sold at judicial sale and the vendor may take a deficiency judgment for the balance. ${ }^{90}$ Laske v. Lampasona, ${ }^{91}$ upon which the most recent appellate case ${ }^{92}$ relied in part in framing its nontraditional specific performance decree, actually called for the traditional approach except where the contract was essentially executed by payment of all funds into escrow. Thus, Laske merely allowed specific performance of an escrow that had been executed by both parties; the only act remaining would be that of the escrow agent and the agent's disbursal was the extent of the order.

But even if specific performance is hikely to lead to judicial sale and a deficiency judgment, this should solve the vendor's problem, given a solvent vendee. It will not do so, however, until the extent to which the California anti-deficiency legislation is apphicable to a land contract has been resolved. Code of Civil Procedure section 580b provides:

No deficiency judgment shall lie in any event after any sale of real property for failure of the purchaser to complete his contract of sale, or under a deed of trust, or mortgage, given to secure payment of the balance of the purchase price of real property ....

The easy answer to this section is that it is intended to prevent a deficiency judgment only where a land contract is used as a security device, i.e., where

88 Goldsworthy v. Dobbins, 110 Cal. App.2d 802, 243 P.2d 883 (1952); Moser v. Pearce, 124 Cal. App. 478, 12 P.2d 977 (1932).

80 See, e.g., Sparks v. Hess, 15 Cal. 186 (1860); Longmaid v. Coulter, 123 Cal. 208, 55 Pac. 791 (1898); cf. Cohn v. Valentine, 88 Cal. App. 430, 263 Pac. 846 (1923); Laske v. Lampasona, 89 Cal. App. 2d 284, 200 P.2d 871 (1948).

80 Sparks v. Hess, Longmaid v. Coulter, Cohn v. Valentine, and Laske v. Lampasona, suppa note 89.

91 Suspra note 89.

92 Goldsworthy v. Dobbins, supra note 88, rebed in part upon Laske. The other case upon which Goldsworthy relied, Moser v. Pearce, supra note 88, may or may not support it. In Moser the court seems to have believed that the vendor would not have a vendor's hen (it being his own property) regardless of the decree, and thus there could be no judicial sale. The court was wrong on both counts. To the extent the court insists upon a vendor's lien to foreclose, the vendor has it when the decree passes title. But a lien is not necessary because the court can order a sale to liquidate the "security" even though the vendor retains title. Longmaid v. Coulter, supra note 89. 
a land contract is "given to secure payment of the balance of the purchase price ... ." ${ }^{293}$ Certainly its inclusion with a mortgage and a deed of trust indicates this to be the legislative intent.

But the supreme court has yet to distinguish between the security device contract and the deposit receipt contract with respect to other remedies. Freedman used security device arguments to reach what does not seem the proper earnest money contract result. The installment cases use Freedman to reach their result. The damage provisions of the code are applied indiscriminately to all contracts. And, in another context, the court has disregarded the language of section $580 \mathrm{~b}$ to assure accomplishment of the statute's purpose. ${ }^{94}$ One is well advised, therefore, not to rely upon the language of section $580 \mathrm{~b}$.

Assume the first case to reach the court is one where, as seemingly often happens, ${ }^{95}$ the deposil receipt form includes the installment terms with an acceleration clause. If the buyer breaches after the fifth installment, it is clearly a default under a security instrument and section $580 \mathrm{~b}$ applies. But if the buyer breaches after the initial deposit, the seller's suit is for specific performance of only the earnest money phase of the instrument, i.e., the agreement on the part of the buyer to buy and to pay the now accelerated price. So under the easy analysis this is not a security device but only an agreement to buy and thus is not within section $580 \mathrm{~b}$.

But the buyer will point out that the price is accelerated as a part of the security phase of the instrument, that even though his agreement was to buy for a gross price it was also an agreement to do so over an extended period of time and acceleration upon default is part of the security device. Thus, he would argue, by removing the extended period of time with the acceleration clause, the court is specifically enforcing the security aspect of the instrument and, therefore, a deficiency judgment is prohibited by section $580 \mathrm{~b}$.

If the court should accept this argument, it also will have decided, erroneously, the case where the deposit receipt calls for the buyer to execute a separate installment contract and the buyer breaches after the imitial deposit. As a defense to the seller's specific performance action, the buyer there could urge with equal validity that even though he agreed to purchase, he agreed to do so only over an extended period of time by the later execution of the installment contract. Thus, every marketing instrument becomes, in effect, a security device within the prohibitions of section $580 \mathrm{~b}$.

93 The other side of the argument could be that gramatically the "given to secure" language seems to modify only "deed of trust, or mortgage" and that historically it was in the section before the section was amended to include the contract of sale.

94 Brown v. Jensen, 41 Cal. 2d 193, 295 P.2d 425 (1953).

95 See, e.g., Post v. Palpar, Inc., 184 A.C.A. 711, 7 Cal. Rptr. 823 (1960) ; Cain v. Hunter, 161 Cal. App. 2d 808, 327 P.2d 583 (1958). 
The form of the decree also suggests another argument for a buyer trying to hide behind section $580 \mathrm{~b}$ after breaching his earnest money agreeinent. Mechanically the decree is often described as passing title to the vendee and the sale is then the foreclosure of the vendor's lien. ${ }^{98}$ The vendor's lien is an implied statutory lien to secure for the seller the amount of the unpaid purchase price. ${ }^{97}$ Thus, even with a pure earnest money contract calling for cash payment of the price, a specific performance action by the vendor becomes an action to foreclose a lien held by the seller as security for the unpaid purchase price, and a deficiency judgment against the buyer is one following a sale for failure of the purchaser to complete his contract of sale, all as described by section $580 \mathrm{~b}$.

Again, the answer seemingly lies in the language of section $580 \mathrm{~b}$. The section refers to a contract "given" to secure. It is, therefore, applicable only to a consensual security device and a vendor's lien simply does not fit this description..$^{8}$ But this answer would make section $580 \mathrm{~b}$ inapplicable also to the installment contract. There too the sale is often conceptualized as a foreclosure of the vendor's lien and thus the judgment follows foreclosure of a lien that was not "given." So again the question must be answered solely in terms of the overall inapplicability of section $580 \mathrm{~b}$ to the nonsecurity instrument.

Unless the court distinguishes between the marketing and security instrument based upon purpose or the intent of the parties, these technical section $580 \mathrm{~b}$ arguments could so confuse the issue that they could become law. The result would be that the seller could have his earnest money contract specifically enforced, but enforced only to the extent that a judicial sale is ordered of what had been his own slightly clouded property. $\mathrm{He}$ would in all probability realize less on the forced sale than he would have realized had he sold it himself, and he is left without a deficiency judgment against the vendee. If the vendor should bid in, not only is he left without any action against the vendee (even though he has recovered nothing), but he would find his property subject to the vendee's statutory right to redeen for a year following the sale. ${ }^{99}$ After the expense of litigation, the successful

88 See, e.g., Laske v. Lampasona, supra note 89 . Foreclosure can be of the vendor's "security" interest, however; passage of title in order to have a vendor's hen to foreclose is unnecessary. Longmaid v. Coulter, supra note 89.

97 Car. CIv. Code $\$ 3046$ : "One who seils real property has a vendor's hen thereon, independent of possession, for so much of the price as reanains unpaid and unsecured otherwise than by the personal obligation of the buyer."

98 The vendor's lien is impled only in favor of the seller who took no specific security for the price. Any specific security, even a lien reserved in the grant itself, is something other than a vendor's lien (most often, because of the statutory presumption, Car. Crv. CodE $\$ 2924$, it is a mortgage). See Dingley v. Bank of Ventura, 57 Cal. 467 (1881).

99 Weil v. Barthel, [Rowland v. Barthel, 263 P.2d 130 (Cal. App. 1953)], 279 P.2d 544 (Cal. 1955), superseded (after rehearing) on other grounds, 45 Cal. 2d 835, 291 P.2d 30 (1955); see also Ward v. Union Bond \& Trust Co., 243 F.2d 476 (9th Cir. 1957). These, of course, are 
vendor then would have no personal judgment against the vendee, no further claim against him, and his property (assuming he bid in) would be subject to a one-year right of redemption allowing the vendee to take advantage of any increase $i m$ its value. Even if he can make a profitable resale during the year of redemption, the vendee could probably redeem and take the profit of the sale from him without even having to raise the money required to do so. ${ }^{100}$

Perhaps the vendor should sue for damages instead. In Royer v. Carter, ${ }^{101}$ decided shortly after Freedman, the court held, as one would expect it to hold pursuant to Civil Code section 3307 , that the vendor may recover the difference between the contract price and the value of the property at the time of the breach. But no one suggested in Royer that this too may be a deficiency judgment.

Assume again a contract on a deposit receipt form including the installment terms and used both as the earnest money agreement and as the security device. If the buyer has made the original deposit and the first of seventy-two monthly payments prior to his breach, the seller might sue for damages under section 3307 alleging and proving that on the date of the breach the property was worth less, call it $\$ 5,000$ less, than the contract price. It follows, under Royer, that he is entitled to a judgment for $\$ 5,000$. Thus, the seller now has the property ${ }^{102}$ and he is $\$ 5,000$ to the good; the very result Code of Civil Procedure section 580b purports to prohibit.

The seller could be expected to point out that section $580 \mathrm{~b}$ refers to a deficiency judgment after a sale and urge that since here there was no judicial sale section $580 \mathrm{~b}$ is inapplicable. But Brown v. Jensen ${ }^{103}$ decided that a deficiency judgment is not the difference between the price bid at the sale (or fair value) ${ }^{104}$ and the contract price or lien; instead, it is any amount

installment cases. The results described in the text are the results under the installment instrument. The purpose of applying the cases to the marketing contract is to demonstrate that they should not be so applied.

100 See Bessinger v. Grotz, 66 Cal. App. 2d 947, 153 P.2d 369 (1944); Car. Code Crv. Proc. 8707 . To do it without investing any money, he would have to carry Bessinger to its logical conclusion and "redeem" by affirming the vendor's profitable resale, thus leaving all of the proceeds of the resale available to be credited toward the redemption price. The venclor would then keep that part of the resale price which represents the amount for which he bid in (plus costs, etc., as provided in CAL. CODE Crv. Proc. 8 707) and the excess would belong to the redeeming vendee. A purely cash sale might leave some "tenant in possession" problems, however, and, as a practical matter, if the new buyer is willing to take the property at the same or perhaps a shightly lower price than that called for in his arrangement with the original vendor, the vendee with his assured profit would have little difficulty in attracting sufficient cash to effect a standard redemption.

10137 Cal. 2d 544, 233 P.2d 539 (1951).

102 If the buyer is in possession he might have to couple an ejectment count and possibly a quiet title count (particularly if anything is of record) with his damage action, but the result (retention of the property and a personal judgment) remains the same.

10341 Cal. 2d 193, 295 P.2d 425 (1953).

104 CAL. Code Crv. Proc. $\$ 726$ thus limits the amount of a deficiency. 
in excess of the value of the property. In other words, only the property is answerable for the indebtedness whatever the form of the vendor's action and the presence or absence of a judicial sale has nothing to do with it. ${ }^{105}$

Except where the security is exhausted, Code of Civil Procedure section 726 prevents an action independent of the security under the other security devices, but section 726 does not apply to the land contract. ${ }^{108}$ Thus, the mortgage or deed of trust and the land contract are equatable in this context only where the security under the former instruments has been exhausted. And it was in this context that Brown decided that a sale is not a prerequisite for a deficiency judgment. So given an installment contract (a security device), there is little question that the court will refuse a patent evasion of section $580 \mathrm{~b}$ through the guise of an action for damages.

But if the buyer had breached after the original deposit, surely the court would not refuse a benefit of the bargam judgment under a nonsecurity contract. However, if a land contract is a land contract regardless of purpose, perhaps (because the result is proper under a security contract) section $580 \mathrm{~b}$ will prevent a benefit of the bargain award where only the initial deposit ${ }^{\mathbf{1 0 7}}$ has been paid under an integrated marketing-security contract. If so, the case of the deposit receipt looking toward a separate installment contract or even a separate deed of trust also will be within section $580 \mathrm{~b}$ and this neans that Royer $v$. Carter will not stand up against a section 580b attack. Civil Code section 3307 then becomes meaningless except as a measure of the vendor's actual damage when the vendee seeks restitution.

Ridiculous? Of course it is. So far it appears that the vendor cannot rely upon a liquidated damages clause, that he cannot get meaningful specific performance, and that he cannot recover a benefit of the bargain judgment, notwithstanding the fact that he sought his remedy for breach of the nonsecurity earnest money contract or deposit receipt. To reach this result we have had to adopt a premise to which, fortunately, the California Supreme Court is not yet specifically committed, viz., that land contract earnest money equals land contract security device. The difference between the two is important in determining the validity of a liquidated damages clause -and the court in Freedman chose not to look at the difference. It is the anti-deficiency legislation, however, that compels reference to the distinction and at least two appellate cases have considered it.

105 See also Jeanese, Inc. v. Surety Title \& Guarantee Co., 176 A.C.A. 4, 1 Cal. Rptr. 752 (1959).

106 Longmaid v. Coulter, 123 Cal. 208, 55 Pac. 791 (1898).

107 The initial deposit is, after all, the first installment under an integrated contract. Usually, though, its earnest money or binder function causes it to be treated separately by the parties. 
In Kerrigan v. Maloof ${ }^{108}$ a defaulting bidder at a judicial partition sale claimed that the action brought by the referee for the difference between the defendant's bid at the first sale and the amount realized upon the second sale was an action for a deficiency judgment after a sale resulting from the buyer's failure to fulfill the contract of sale and was thus prohibited by section 580b. In denying the defense the court said that Code of Civil Procedure section 785 expressly authorizes the deficiency and held that the specific (section 785) rather than the general section (section 580b) controls where they conflict. The court also suggested that section $580 \mathrm{~b}$ applies only where credit is involved and not to a cash judicial sale.

Later, in Goldsworthy v. Dobbins, ${ }^{109}$ the problem arose in an action for specific performance of an earnest money contract. The defendant claimed that the specific performance decree ${ }^{110}$ in economic effect was a deficiency judgment and was proscribed by section $580 \mathrm{~b}$. The court, happily, threw out the defense. But in doing so it followed Kerrigan to the letter, holding that if section $580 \mathrm{~b}$ apphed, the specific performance sections of the Code $\mathrm{C}^{111}$ were repealed by implication and that instead, per Kerrigan, the specific (Civil Code sections 3384-95) controlled the general section (section $580 \mathrm{~b}$ ). The difficulty is that this argument proves too much-it is equally applicable to a suit for specific performance of the installment or security contract $^{112}$ or to a Civil Code section 3307 benefit of the bargain claim ${ }^{113}$ under an installment device. And if section 3307 (benefit of bargain) or sections 3384-95 (specific performance) control Code of Civil Procedure section $580 \mathrm{~b}$ in the installment cases, there is nothing left in section $580 \mathrm{~b}$ that prevents a deficiency judgment under any land contract, the one form of action statute being inapplicable. ${ }^{114}$ But this total removal of the land contract from section $580 \mathrm{~b}$ simply will not occur. Civil Code sections 3307 and 3389-95 are not specific in the same sense as Code of Civil Procedure section 785 . Section 785 deals with a particular result under a particular

10898 Cal. App. 2d 605, 221 P.2d 153 (1950).

109110 Cal. App. 2d 802, 243 P.2d 883 (1952).

110 The customary decree is one ordering the defendant to pay the price and take a deed or, upon the defendant's failure to pay, ordering the property to be sold by judicial sale with a vendor's deficiency judgment. The decree in Goldsworthy, however, changed the second alternative to substitute a judgment for the price and an order to the vendor to convey after satisfaction of the judgment. Although he would have had a clearer argument under the traditional form of decree, the defendant in Goldsworthy addressed his anti-deficiency argument to the judgment for the price which would at that time have been a difficult argument even in the context of a security contract because Brown v. Jensen, supra note 94 , had not yet been decided.

111 CaL. Crv. Code $\$ \$ 3384-95$.

112 Particularly if the court will apply the Goldsworthy type decree to the acceleration upon breach security contract.

113 Assuming this, rather than rental value, to be a proper measure under the installment device. Although commonly said to be, it probably is not.

114 CaL. Code Crv. Proc. $\$ 726$. 
procedure. Sections 3307 and 3384-95 relate to remedies, but if the specific statute is to control the general, it is probably as meaningful to say that the specific subject is the deficiency judgment (so that section $580 \mathrm{~b}$ controls) as it is to say that the specific subject is specific performance or damages (so that section 3307 or sections $3384-95$ control).

There is a more appealing aspect of the court's adoption of Kerrigan. The court accepted Kerrigan's suggestion that section 580b applies only to a contract where "credit" is involved and pointed out that the deposit receipt contemplated cash. ${ }^{115}$ "Cash" and "credit" are terms too narrow to solve the problems involved; but what the court undoubtedly meant was that section 580b precludes a deficiency judgment and thus relegates the creditor to the property for satisfaction where the primary purpose of the instrument is security and not where the primary purpose is to bind a sale. Because of its reliance on Kerrigan, Goldsworthy is not the clear precedent for differentiation that it might have been. It seems inevitable, lowever, that the California courts will differentiate between the contracts based upon purpose and clearly the anti-deficiency legislation will not interfere with a seller's action for specific performance or for damages upon the buyer's breach of the marketing instrument.

\section{Damages}

One problem of the marketing instrument that will not be solved by separating marketing from security lies in the proof of damage area. Although the anti-deficiency legislation will not be applicable the vendor can still anticipate difficulty in his action for damages. This discussion is intended to illustrate some of the vendor's problems when he seeks damages based upon the buyer's breach. Necessarily, the discussion is limited to actions under contracts that do not have the "exclusive-money-remedy" type liquidated damages clause described earlier, but the existence of evidentiary problems under a contract without the clause is a further argument for an enforceable hquidated damages clause.

Civil Code section 3307 provides that the vendor's damages are the difference between the contract price and the value of the property to him. According to Royer v. Carter ${ }^{118}$ he can recover the difference between the contract price and the value at the time of the breach, plus incidental expenses incurred in resale. To avoid an election, the vendor should notify the buyer that he is retaining the deposit as a setoff against actual damage. He should anticipate the defense that a buyer under the California Real Estate Association form may claim to have been misled into thinking that

115 It was cash from the seller's standpoint in that the buyer was to obtain third party financing-thus, in the sense that the contract in question would never be used as a security device, it was a cash sale.

11637 Cal. 2d 544, 233 P.2d 539 (1951). 
his deposit was the limit of his liability, ${ }^{117}$ but it is unlikely that the buyer will be able to show that he actually relied upon this in entering into the contract. Perhaps a buyer will someday be successful in showing reliance as inducing his default and perhaps a court may someday accept it, but so far estoppel does not seem to have been troublesome either at the execution or at the breach stage. ${ }^{118}$

The time element, however, can create some real problems. In Royer the vendor resold for $\$ 18,500$ three months after the breach. Opinion evidence placed the market value of the property at $\$ 22,500$ (or better) at the time of the breach. The contract price was $\$ 24,000$; defendant's breach occurred within a month of the execution of the contract. Because it liad awarded the seller the difference between the contract and the resale price (apparently the true value at the time of the resale because of a rapidly declining inarket), the trial court was instructed to re-try the damage issue and to limit damages to the difference between the contract price and the value at the time of breach. Except for a concurring opinion, the court apparently was not concerned with the idea that the value to the seller at the time of the breach may really be the amount for which the seller can sell two or three months later, particularly in a rapidly declining market.

It may seem coniforting to the seller not to be concerned with diligence or with mitigating damages-he is bound by the value at time of the breach, so diligence is irrelevant. ${ }^{119}$ In fact, it is possible that consideration of value only at the time of the breach may result in a higher: recovery than if the test were qualified by a diligent resale requirement. The multiple listing situation, for exanple, may cause the breacl itself to be an artificial temporary depressant upon the value of the property so that the vendor, if he defers his resale, may recover substantially more than his actual loss, his damages being ineasured solely by comparison between the contract price and value at a time of temporary depression..$^{120}$ But even though the courts say that the vendor is entitled to the profit of a rising market, a comparison of the cases convinces one that a short-tern artificial reduction in value will not lead to a recovery in the face of a profitable resale. It is the vendor's evidentiary problems that bring on his difficulty.

In Fleischer v. Cosgrove, ${ }^{121}$ for example, the seller resold within thirty days at an $\$ 8,000$ loss. He sued the defaulting first buyer for the $\$ 8,000$

117 This claim was made and rejected in the Royer case. See, also, the discussion of the ambiguous form in the earlier liquidated damages section, text at notes 58-69 supra.

118 Cf. Fleischer v. Cosgrove, 145 Cal. App. 2d 14, 301 P.2d 911 (1956), where the buyer successfully urged, in the trial court at least, this kind of reliance, but under a contract which seemed to a greater extent than do the present forms to limit the seller to a choice between specific performance and hquidated damages.

110 Van Buskirk v. McClenahan, 163 Cal. App. 2d 633, 329 P.2d 924 (1958).

120 Bouchard v. Orange, 177 A.C.A. 607, 2 Cal. Rptr. 388 (1960).

121145 Cal. App. 2d 14, 301 P.2d 911 (1956). 
and attempted to prove value at the time of the breach by his own testimony supported by that of a realtor to the effect that the property was then worth only the resale price. ${ }^{122}$ The defendant offered no evidence as to the value of the property. The property was a motel, sold first to the defendant for $\$ 117,000$, and then a month after defendant's breach to another buyer for $\$ 109,000$. Surprisingly the trial court cavalierly found that the price bid by the defaulting buyer must have been the true value at the time of the breach on the theory that there was no general drop in property values in the area. Thus, even though he offered no contrary evidence of value, the defendant avoided paying damages simply by showing the amount of his offer; this, according to the appellate court, was sufficient evidence to sustain the trial court's finding. Apparently, to convince the court that the second price was the best he could obtain on fairly umique property within a short period of time, the plaintiff would have had to invest most of his potential recovery in real estate appraisers and expert testimony. If this result could be explained in terms of lack of diligence with respect to the second sale, which seemingly must have motivated the trial court, it would be easier to accept. But to explain it in terms of sufficiency of evidence of value makes one wonder what evidence is needed for the vendor to sustain his burden of proof.

When the vendee sues for rescission, the burden of proof theoretically is his. ${ }^{123}$ But here too "bootstrap pulling" is sometimes a good substitute for proof. In Major-Blakeney Corp. v. Jenkins, ${ }^{124}$ for example, the vendor resold unimproved lots at a $\$ 1,200$ loss six months after the vendee's original breach, apparently having atteinpted to sell all during the interim. The vendee, who had the burden of proof, did not offer any evidence of value at the time of the breach, but he convinced the court that the property was worth the original contract price by showing that he was still willing to pay it. Apparently the vendee alternated between breach and perforinance and, after several delays, the vendor set a final day for closing. The vendee again failed to perform but, consistent with his past record, offered to do so shortly thereafter. Perhaps the vendor should have accepted, but perhaps, too, the vendor expected nothing but further problems if he continued to try to accommodate him. In any event, the buyer's claimed willingness to perform shortly after his final breach was sufficient evidence for the buyer to recover his deposit, viz., to sustain his burden of proving that the seller liad not been damaged notwithstanding his diligent resale at a loss.

Iromically, though the installment contract seems to have been the cause of the whole reform movement, it is the deposit receipt that is inost affected

122 The realtor's testimony may have been in the form of a stipulation; this is not clear in the opinion.

123 See, e.g., Freedman v. The Rector, 37 Cal. 2d 16, 230 P.2d 629 (1951).

124121 Cal. App. 2d 325, 263 P.2d 655 (1953). 
even in the damage area. In an installment contract, rental value of the property must be considered ${ }^{125}$ and this avoids focusing upon value at any particular time, unless, of course, somebody converts the measure to a difference test by compelling a judicial sale of the property. ${ }^{126}$

Since deduction of rental value will normally leave the parties in at least a realistic situation under an installment contract, one would expect the courts to look for new elements to lielp the vendor in the deposit receipt situation. And some have. California appellate courts have said that trial courts should consider the time the property is off the market, ${ }^{127}$ taxes accruing during that time, ${ }^{128}$ breacl as inherently a recessive factor, ${ }^{129}$ activity of the market, ${ }^{130}$ and the several other factors that can influence value. ${ }^{131}$ But these are rarely matters of direct evidence; they are more often factors considered by an expert in arriving at an opinion of value, and the cost of experts can rapidly destroy the advantage of recovering a judgment.

If it were possible to find experts that were good enough to consistently place the value of property within a two to three percent margin of error, there might be at least a technical justification for allowing its cost to swallow the litigation. But as most appraisers will admit, they are not that good. And certainly in the smaller cases the litigants are inclined to rely upon resale figures and their own testimony to establish value at the time of the breach. But with few exceptions ${ }^{132}$ the cases demonstrate that resale at a loss is not particularly convincing evidence of value at the time of

125 In Bird v. Kenworthy, 43 Cal.2d 656, 277 P.2d I (1954), for example, the vendee breached an installment contract (personal property conditional sale contract) after paying $\$ 24,000$ of the $\$ 29,500$ purchase price. The property was worth $\$ 28,000$ at the time of repossession. But because the plaintiff showed reasonable rental value to have been $\$ 37,400$, the court held that his keeping the payments of $\$ 24,000$ plus the property worth $\$ 28,000$ did not result in a forfeiture under the Freedman test; the vendor could have made more, the court pointed out, if he had simply rented the property. The real property cases supporting the rental value ineasure for the installment contract include Ward v. Union Bond \& Trust Co., 243 F.2d 476 (9th Cir. 1957) ; Heintzsch v. LaFrance, 3 Cal. 2d 180, 44 P.2d 358 (1935); Roberts v. Lebrain, 113 Cal. App. 2d 712, 248 P.2d 810 (1952); Nelson v. Dangerfield, 125 Cal. App. 2d 146, 269 P.2d 953 (1954).

126 Whether the measure is difference value because of a judicial sale or rental value in the absence of sale, it is neverthcless a deficiency in the imstallment context and is therefore important only in deciding whether or not the vendor nust make restitution.

127 Wolfe v. Heller, 86 Cal. App. 2d 696, 195 P.2d 36 (1948).

128 Major-Blakeney Corp. v. Jenkins, 121 Cal. App. 2d 325, 333, 263 P.2d 655, 662 (1953). 129 Bouchard v. Orange, 177 A.C.A. 607, 2 Cal. Rptr. 388 (1960).

${ }^{130}$ Van Buskirk v. McClenahan, 163 Cal. App. 2d 633, 329 P.2d 924 (1958).

131 Cf., also, Mathews v. McArthur, 119 Cal. App. 2d 196, 253 P.2d 1068 (1953); Shurtleff v. Marcus Land \& Inv. Co., 59 Cal. App. 520, 211 Pac. 244 (1922).

132 See, e.g., Bouchard v. Orange, supra note 129. Such cases as Furst v. Scharer, $119 \mathrm{Cal}$. App. 2d 605, 260 P.2d 198 (1953), where the seller retains what he bas only because the buyer does not prove a forfeiture in the absence of resale, cannot really be counted on the seller's side of the issue. 
the breach, while resale at a profit is so conclusive it practically precludes recovery. ${ }^{133}$ Although the court could have taken Civil Code section 3307's "value to him" language to imply a diligence test, it did not; so the vendor, if he is really interested in damages, had better be prepared to invest in expert testimony even if his resale was at a loss.

\section{Distinction Based on Purpose}

Except for the proof of damage difficulties, most of the remedial problems of the deposit receipt or earnest inoney contract arise because the security device is read into the contract. Liquidated damages, for example, legitimately belong in the marketing contract. Specific performance without judicial sale or redemption is proper under the marketing instrument, and certainly the anti-deficiency legislation has no application to the marketing contract. While the court has not yet distinguished between the contracts for other remedial purposes, the anti-deficiency legislation so glaringly illustrates the necessity for the distinction that it will there be made and undoubtedly will work back through all of the other remedial problems -and then they will no longer be problems.

It is easy in most cases to separate the earnest money contract from the security device. The early writers seemed to have assumed some general differences between earnest money and installment contracts. ${ }^{134}$ Perhaps this is about as specific as the distinction can be, i.e., a vague purpose test, leaving the precise defimition to be resolved as a question of intent in each case.

Compare the general distinction with some of the legislative and proposed legislation distinctions which, supposedly, require more specificity. Maryland defines the security mstrument as one having five or more installments; ${ }^{135} \mathrm{New}$ York legislative proposals include more than one payment ${ }^{136}$ and more than two payments after the initial payment; ${ }^{137}$ and a proposal for model legislation would draw the line where a part of the purchase price was due, in the absence of default, more than one year after execution of the contract. ${ }^{138}$ Any of these tests will work in the overwhelm-

133 Practically all of the cases cited earlier in this section are support for this. For an extreme example see Hollypark Realty Co. v. MacLoane, 163 Cal. App. 2d 549, 329 P.2d 532 (1958), where the inere fact of resale, which incidentally was at a loss, seems to lave been itself sufficient to preclude a successful action for damages.

134 E.g., Ballantine, Forfeiture for Breach of Contracts, 5 MINN. L. REv. 329 (1921); Corbin, Right of Defaulting Vendee to Restitution of Installments Paid, 40 YaLE L.J. 1013 (1931); see also, Restatedent, Contracts $\$ 357$ (1932).

135 MD. ANn. Code art. 21, 3118 et seq. (1957).

138 N.Y. Legis. Doc. No. 65 (in) (1937).

137 N.Y. Legis. Doc. No. 65 (E) (1938).

138 Howe, Forfeitures in Land Contracts, in Current Trends IN State Legislation 417, $.524(1953-54)$. 
ing majority of cases, but these are the cases where the purpose is so clear that precise definition is not required in the first place.

Instead of an arbitrary, mechamcal division the distinction should he in the purpose for which the parties are using the contract. Actually, the problem is the same as the problem of separating a mortgage from an absolute conveyance or an option to repurchase. In the land contract as in the mortgage cases, the problem actually becomes whether or not the "equity of redemption" should be avoided. Certainly no one would say the mortgage problem should be decided by defining the mortgage in terms of its appearance. And because the same issue is to be decided, i.e., the applicabihty of the security debtor's protective devices, in making the installmentmarketing distinction, the approach should be the same. Arbitrary lines and mechanical distinctions simply invite mechamical evasion devices. ${ }^{199}$ And mechamical lines are of too much aid in the borderline cases; ${ }^{140}$ they prevent the court from looking at the real issue, intent.

Intent may be evidenced by several factors imcluding time, change of possession, number of installments, percent payable under the contract, other financing mvolved, and so on, but the issue remains intent. The court has had little trouble with it in other contexts ${ }^{141}$ and it will have little difficulty with it here once it confirms that making the distinction is imperative $\mathrm{m}$ view of the changes in remedy that Freedman and Ward have brought.

\section{IV}

\section{THE SECURITY CONTRACT}

It seems futile to urge, as some have, ${ }^{142}$ that the land contract reform movement has gone too far. Certainly if the reforms are applied indis-

139 A good example, although in a somewhat different context, is Scarbery v. Bill Patch Land \& Water Company, 184 A.C.A. 89, 7 Cal. Rptr. 408 (1960), where a senior deed of trust provided for acceleration upon sale thus forcing the parties to give an installment land contract the appearance of a lease with an option to buy. The inechanical difference was sufficient to prevent acceleration of the senior instrument, but when a forfeiture issue arose under the "option" it seemingly turned out to be a land contract after all.

140 E.g., where the deposit receipt form is used for both purposes as in Post v. Palpar, Inc., sucpra note 95, or where the "down payment" is spread over several monthly installments as in Cain v. Hunter, 161 Cal. App. 2d 808, 326 P.2d 583 (1958).

141 See, e.g., Watson v. Edwards, 105 Cal. 70, 38 Pac. 527 (1894); Orlando v. Berns, 154 Cal. App. 2d 753, 316 P.2d 705 (1957); Scarbery v. Bill Patch Land \& Water Co., supra note 139.

142 See, e.g., Rudolph, The Iratallment Land Contract as a Jisnior Security, 54 Mrcr. L. Rev. 929 (1956). Professor Rudolph's arguments, however, presuppose a jurisdiction having a more cumbersome mortgage enforcement procedure than that of California, and they relate mainly to jurisdictions which have not yet undertaken a similar reform. The points he makes are excellent; it is simply too late, at least as far as the Freedman approach is concerned, in California. 
criminately rather than solely to the security type device that created the problems, the reform movement is not reform but is, instead, chaos. As limited to the security instrument, however, the broadening of the vendee's protection to avoid the unconscionable results of the past ${ }^{143}$ is beyond impartial criticism even if it has gone so far that it has shifted the balance of power to the vendee. The security device to be used is normally the vendor's choice. If the courts have so modified the vendor's remedies that he no longer finds the installment contract an attractive security device, he will, presumably, choose a power of sale mortgage or a deed of trust to accomplish his purpose. And this does not seem catastrophic-there is, after all, bittle reason to give one of three devices intended to accomplish a single purpose extensive remedial advantages over the others. The "old saw," of course, is that private enforcement and forfeiture is beneficial to the debtor because it enables him to get much closer secondary financing. But this is Califorma; granting the validity of that approach in states having awkward or cumbersome mortgage enforcement systems, it is not particularly impressive here where the creditor can realize upon his mortgage or deed of trust security within one hundred and ten days ${ }^{144}$ under a sale that then becomes in all respects final. He is not burdened by a long period of "rent free"145 possession during a redemption period; there is no redemption period following sale under the power. ${ }^{146}$ Any backtracking from the Barkis $^{147}$ to the Freedman ${ }^{148}$ approach, and perhaps even from Ward, ${ }^{148}$ will not be in the installment contract context since it was the abuses under this device that brought on the reform in the first place.

The only meaningful inquiry that can now be made is one relating to the advantages the installment contract offers the vendor over the power of sale mortgage or deed of trust. Since the installment contract's justification is that in theory its quick, inexpensive enforceability permits closer financ-

143 The unconscionable results are, of course, the forfeitures to which almost everyone who has written about land contracts, even today when it is no longer a problem, addresses his arguments, e.g., 7 U.C.L.A.L. REv. 83 (1960). See Vanneman, Strict Foreclostures in Land Contracts, 14 Mnnv. L. Rev. 342 (1930); Ballantine, Forfeiture for Breach of Contract, 5 Minn. L. Rev. 329 (1921).

144 Ninety days from notice of default CAL. CIv. Code $\$ \S 2924,2924 a, 2924 b$, plus twenty days notice before date of sale CAL. CODE CIv. Proc. $\$ 692$.

145 Following a sale where there is a statutory right of redemption, the debtor would be liable to the purchaser at the sale for value of use during the redemptive period. CAL. Code Crv. PROC. § 707. But usually this is a right against a judgment-proof debtor-thus, realistically, possession is rent free.

146 The debtor can reinstate the mortgage or deed of trust prior to sale, CAL. Crv. CoDE $\$ 2924 c$; but has no statutory right of redemption following the sale. CAL. Crv. CoDE $§ \S 2924 a$, $2924 \mathrm{~b}$.

147 Barkis v. Scott, see note 20 supra and accompanying text.

148 Freedman v. The Rector, see note 25 supra and accompanying text.

149 Ward v. Union Bond \& Trust Co., see note 28 supra and text thereto. 
ing, ${ }^{150}$ there remains no purpose for it if it is no longer summarily enforceable and is, in fact, often more cumbersome than the mortgage or deed of trust. Its usefulness to the vendor depends, in part, upon the vendee's rights -his equity of redemption, his right to compel judicial sale, his statutory right of redemption, his deficiency judgment protection and his right to restitution. Much of what is here relevant has been covered in the marketing contract section and repetition, other than occasional repetition to put in context, seems unnecessary. Many of the results that were there absurd are here appropriate. To the extent this section is devoted to saying so, it will be only to amphify with hberal incorportion by reference.

\section{A.Vendee's Equity of Redemption}

Before the willfully defaulting vendee was given the right to refuse restitution and insist instead that the vendor perform the contract that the vendee had breached, ${ }^{151}$ the possibility of a equity of redemption was not particularly discouraging to the installment vendor. The fact that the vendee could not with impunity repudiate to harass or to try to force acceleration of the nonaccelerable instrument left the occasional redemption possibilities unimportant. Thus, the significant change lies in Ward's extension of the right to specific performance, viz., the equity of redemption, to the willfully defaulting vendee. If the federal court's decision in Ward is not a part of Califorma law, the land contract remains at least an acceptable vendor's security notwithstanding Freedman, Barkis and the other reform cases. If it is, the contract is obsolete as a security device.

To appreciate the significance of $W a r d$, it is necessary to consider, individually, all three of the changes Ward would make in Califorma law. Ward assumed that in the vendor's action to quiet title the willfully defaulting vendee would be entitled to an interlocutory decree affording him an opportunity to perforn before the vendor's title could be quieted. It then held that the willfully defaulting vendee could by his own action compel such redemption and refuse the vendor's proferred restitution without, incidentally, proving that a forfeiture in the technical sense would otherwise result. Finally Ward suggested that the vendee, by a proper showing, could force a judicial sale followed by a statutory period of redemption.

Not even Ward's first assumption may be considered as settled by the California courts. It may be, or it may become, the law that the willfully defaulting vendee can insist upon a period within which to redeem before the vendor's title is quieted, but this is not as clear as Ward would make it appear. Again a little history may help resolve the question. For years a nonwillful defaulter has had an equity of redemption in the sense that the

150 See, e.g., 27 CArrF. L. REv. 583 (1939), Rudolph, suppra note 142.

151 Primarily Ward v. Union Bond \& Trust Co., 243 F.2d 476 (9th Cir. 1957) ; see generally, notes 28-33 supra and text thereto. 
court would not enforce the forfeiture. ${ }^{152}$ While it was true that the vendor, if the title were not clouded and if the vendee voluntarily relinquished possession, could retain the excess paid over actual damage as a part of his private enforcement, it was also true that the vendor could not quiet his title or regain possession without the court affording the nonwillfully defaulting vendee some opportunity to perform. ${ }^{153}$ This does not mean, of course, that the land contract could not be strictly foreclosed; it could be, but only im the sense that a judicial sale was not required. Before the final order quieting the vendor's title, however, the innocent defaulting vendee would be given a limited opportunity to perform and thus avoid any forfeiture. In 1949 the nonwillful defaulter's rights were expanded to afford him his own action for redemption, i.e., to reinstate the contract, whether or not the vendor souglit any affirmative action. ${ }^{154}$

In the absence of close analysis, the rights of the willful defaulter seem to have stopped short of the first step, viz., he apparently was denied even the interlocutory decree designed to give a period to redeem before the quieting of title, Civil Code section 3369 notwithstanding. It is arguable that this apparent denial is based upon "clean hands" and is, therefore, existing authority against Ward. ${ }^{155}$ Since section 3369 calls for equitable assistance, the "clean hands" theory has a certain amount of validity. But the only clear holding against the willful defaulter in this context is a somewhat confused opimion by an intermediate court in Palmer v. McArthur. ${ }^{156}$ Civil Code section 3369 prohibits specific or preventive relief to enforce a penalty or forfeiture in any case; fault is irrelevant. While Civil Code section 3275 compels consideration of fault and provides for affirmative relief to the nonwillful defaulter in his own action, it is irrelevant with respect to the forfeiture problem in the vendor's action. Only section 3369 is relevant in deciding whether or not the court may enforce a forfeiture at the request of the vendor, i.e., whether it may quiet his title without giving the vendee a limited opportunity to perform. But the court in Palmer v. MCArthur held that the willful defaulter was not entitled to the benefit of an interlocutory decree because he was not within section 3275-which has nothing to do with it. Since the confusion between sections 3275 and 3369 no longer exists, neither does Palmer v. McArthur. And there are now cases

162 Car. Crv. Code \$ 3369. See, e.g., Gonzalez v. Hirose, 33 Cal. 2d 213, 200 P.2d 793 (1948) ; Wilson v. Beagley, 186 Cal. 437, 199 Pac. 772 (1921) (cross-complaint for specific performance against assignee, strict foreclosure result); Krotzer v. Clark, $178 \mathrm{Cal}$. 736, 174 Pac. 657 (1918).

153 See footnote 152 supra.

154 Barkis v. Scott, 34 Cal. 2d 116, 208 P.2d 367 (1949), which clearly applied for the first time Cax. Crv. Code \$ 3275. See footnotes 20-23 supra and accompanying text.

15510 Star. L. REv. 355 (1958).

15699 Cal. App. 510, 278 Pac. 1049 (1929) ; cf. Gonzalez v. Hirose, 33 Cal. 2d 213, 200 P.2d 793 (1948). 
where the California courts have given the willful defaulter the benefit of the interlocutory decree even though none have specifically considered its propriety. ${ }^{137}$

This, however, does not lead inevitably to the right of the willful defaulter to refuse restitution and insist, ${ }^{158}$ instead, upon an opportunity to perform even under section 3369. A forfeiture, after all, is avoided by restitution too. But in Barkis the court said that reinstatement is preferable to restitution because of the vendee's difficult burden of proof, and Freedman makes it clear that even the willfully defaulting vendee is to be protected from forfeiture. If reinstatement is the nonwillful defaulter's preferred remedy to avoid a forfeiture, presumably renistatement is also preferable for the willful defaulter ${ }^{159}$ And as limited to the section 3369 area, i.e., to the avoidance of forfeiture in the vendor's action, the California Supreme Court seems to have assumed that fault is irrelevant regardless of remedy. ${ }^{180}$ Whether or not the federal court in Ward was correct in holding this to be California law remains open, but there is at least some support for it.

Whether or not Ward was correct in its next step, in predicting that in the "beyond section 3369" area the willfully defaulting vendee can compel reinstatement by his own action (viz., in predicting that every vendee has a clear equity of redenution) is simply unanswerable. The comparison of the Barkis reasoning with the Freedman result supports it. There is authority both ways in the intermediate courts, ${ }^{161}$ but probably the trend is in favor of Ward. The inost decisive single factor, however, seems to be the tendency of the California court to equate the installneni. land contract with the mortgage or deed of trust.

While the ultinate answer hes in the philosophy of the court-either it does or it does not believe there are reasons for preserving the installment contract as a separate security device-it seenis to be necessary to separate the marketing and security contracts in arguing either side of the issue based upon the Ward result. A good argument against Werd, for example, is that $W$ ard allows the vendee to speculate on value before choosing be-

157 E.g., Nelson v. Dangerfield, 125 Cal. App. 2d 146, 269 P.2d 953 (1954). In Weil v. Barthel, 279 P.2d 544 (Cal. 1955), superseded after rehearing, 45 Cal. 2d 835, 291 P.2d 30 (1955), the court seems to have assumed the interlocutory decree was proper regardless of fault.

158 If the vendor prefers the interlocutory decree to restitution. as he well may in the absence of funds to pay the restitution award, the issue is unimportant. It is the willfully defaulting vendee's right to compel reinstatement that is at issue.

150 The court in Freedman v. The Rector, for example, justified restitution for the willful defaulter in his own action in the "beyond section 3275" area partly because he can get it in the vendor's action under $\$ 3369$. See also Weil v. Barthel, 279 F.2d 544 (Cal. 1955), superseded after rehearing, 45 Cal. 2d 835, 291 P.2d 30 (1955).

160 Compare Baffa v. Johnson, 35 Cal.2d 36, 216 P.2d 13 (1950), and Freedman v. The Rector, 37 Cal.2d 16, 230 P.2d 629 (1951), with Weil v. Barthel, note 159 supra.

181 See note 33 supra. 
tween reinstatement or restitution. ${ }^{162}$ But this realistically argues only against Ward's application to the marketing instrument; an application which for this and other reasons seems unlikely when the contracts are separated by purpose. The installment vendee can also speculate to a limited extent. But unlike the marketing vendee, his liability is based upon (i.e., his refund is reduced by) rental value or difference value, whichever is greater. ${ }^{103}$ So speculation, for him, is not particularly attractive-it is, at least, speculation and not a sure thing.

It remains true that Ward's unrestricted equity of redemption allows the vendee to harass the vendor by consecutive defaults. But he has no greater opportunity for harassment under the contract even with Ward than he would have under the other security devices; in all cases he has an equity of redemption regardless of fault and the statutory penalties under the other two instruments ${ }^{164}$ are no more discouraging than the contractual penalties ${ }^{105}$ found in practically all contracts. So again the effectiveness of the argument depends upon whether the court wants to equate the land contract to the other devices or whether it wants to leave some remedial advantages to it.

Similarly, whether Ward's reinstatement of the contract contemplates specific performance of the entire instrument including the acceleration clause, or whether it means the contract is to be continued without acceleration in the absence of a judicial sale, depends upon the extent to which the court is inclined to carry the mortgage analogy. Under a mortgage or deed of trust, the debtor may reinstate without acceleration for a period of three months following notice of default if the security is to be sold under the power, or at any time prior to the foreclosure judginent if the creditor chooses judicial enforcement. ${ }^{186}$ Under the installment contract, there are indications that the result would be the same. The vendee in Ward wanted to pay the accelerated price so the issue did not arise. But the court made a point of the fact that there had been no acceleration in Peterson $v$. Ridenour, ${ }^{167}$ seemingly, since there was no other reason to talk about it, to indicate that reinstatement without acceleration is also a right of the willfully defaulting vendee. And in Barkis v. Scott ${ }^{168}$ the contract was reinstated

162 See 10 Starr. L. Rev. 355 (1958).

163 The vendor's damages are based upon rental value, but if the value of the property has changed sufficiently the vendor can have a judicial sale which necessarily approaches a difference value test. So given a sharp increase in value, the vendor, by sale, will recapture his interest at least, whereas a market decrease is at the risk of the vendee because he can have restitution only if his payments exceed rental value-difference is there irrelevant. See notes 182-85 infra, and accompanying text.

164 Cas. Civ. Code $\$ 2924$ c.

105 Attorney's fees, for example.

166 Cax. Crv. Code \$2924c.

167135 Cal. App. 2d 720, 287 P.2d 848 (1955).

10834 Cal.2d 116, 208 P.2d 367 (1949). 
under Civil Code section 3275 without acceleration. ${ }^{169}$ Although this remains techmically unsettled, the probabilities are that if the California Supreme Court accepts Ward's equity of redemption, it will carry the mortgage analogy far enough to include reinstatement without acceleration.

Whether or not Ward's total equity of redemption is California law cannot be answered until the California Supreme Court has had an opportumity to consider it. The answer could go either way consistently with California precedent-it is a question solely of the court's underlying approach to the installment contract as a security device. The supreme court seems to have decided to destroy it. If so, Ward will be the California law. In any event, a vendor choosing between the deed of trust or installment contract as a security device should make the choice upon the assumption that it is.

There remains, however, Ward's third step beyond precedent, its suggestion that the vendee by proper showing could force a judicial sale followed by a statutory right of redemption.

\section{Statutory Right of Redemption}

Traditionally the trial court has had the power to order a judicial sale of the property. ${ }^{170}$ But because of the availability of strict foreclosure ${ }^{171}$ and because of the applicability of the anti-deficiency legislation, ${ }^{172}$ foreclosure by sale was rare. Had the choice of remedy following his own breach been the vendee's, undoubtedly the judicial sale would have been the paramount remedy-the vendee in any event would be immune from a personal judgment and, assuming a year for redemption, would have had an additional year's possession together with an additional year's look at values. But the choice was not that of the breaching vendee. Granting that he always had a limited opportunity to complete the contract before the vendor could quiet title, granting that after Barkis the nonwillful defaulter could remstate the contract on his own imitiative, granting that after Freedman the willful defaulter could get restitution in his own action, and even granting that Ward is correct in holding that the willful defaulter can refuse restitution and reinstate, never have the California courts said that he can so name the vendor's remedy that he can compel a judicial sale. ${ }^{178}$

169 In Barkis, however, the vendor previously had refused the vendee's offer to discharge the debt, and by the time of the action the vendee seemed to be having financial problems. Thus, presumably neither party wanted acceleration.

170 Sparks v. Hess, 15 Cal. 186 (1860); Longmaid v. Coulter, 123 Cal. 208, 55 Pac. 791 (1898). As pointed out earher, the sale was either a sale of the vendor's "security" or it was a sale following foreclosure of the vendor's ben, title having passed to the vendee by the decree. 171 In the no sale sense; the vendee still had an opportunity to redeem before the vendor's title was quieted.

172 Car. Code Crv. Proc. $8580 \mathrm{~b}$.

178 For the earlier cases saying so, see Note, 27 CAurF. L. Rev. 583, 584 (1939). For authority since, one can rely only upon the absence of any cases giving him the right. But cf. Weil v. Barthel, supra note 159. 
Ward suggested, however, that to further protect the vendee, the trial court could order a judicial sale, thus giving the vendee a statutory year of redemption. In context, the court's suggestion means that the vendee's showing of possible inability to redeem during an interlocutory period is itself a sufficient basis for the trial court to order the sale notwithstanding the vendor's objection. Neither the vendor's offer of restitution nor his acquiescence in the interlocutory redemption period would be sufficient to prevent the willfully defaulting vendee from insisting upon and getting a judicial sale.

Probably the closest California support for this is Weil v. Barthel. ${ }^{174}$ There the willfully defaulting vendee was successful in obtaining a judicial sale in the vendor's quiet title action, but the opinion does not indicate whether the vendor was unwilling to make restitution and thus himself sought a sale or whether the vendee forced it. At the appellate level the issue was unimportant, ${ }^{175}$ but the case nevertheless is significant upon this issue because the court assumed that the willfully defaulting vendee was entitled either to an interlocutory decree or to a judicial sale. Thus, it impliedly supported Ward's equity of redemption for the willful defaulter, but certainly it fell sliort of Ward's right to conipel a sale by showing inability to reinstate. Again, the ultimate California determination of the issue is unanswerable. But again, if California chooses to carry the mortgage-land contract analogy the whole way, Ward may be right.

The next step is easy. If there is a judicial sale, there will be a statutory year of redemption. While surprisingly unsettled, an opinion that was withdrawn after rehearing in Weil v. Barthel is reasonably clear authority that the statutory redemption period would follow the sale. ${ }^{176}$

In selecting a security device, it seems imprudent to assume that Ward is not law in California. Since Ward leaves the choice of remedies to the intentionally breaching vendee, the seller should assume that the vendee's choice of the vendor's remedies includes restitution, remstatement, or judicial sale with redemption but without a deficiency judgment. And in choosing his security device, the creditor should compare the contract's possible judicial sale and year of redemption with the power of sale available under the other security devices. Thus, he should compare three and one-half month nonjudicial enforcement without post sale redemption ${ }^{177}$ with major litigation resulting in a sale followed by a one-year period of redemption.

174 Supra note 159.

175 The parties instead were concerned with the applicability of the statutory period of redeinption.

176 Weil v. Barthel, suspra note 159. See also Tilley v. Bonney, $123 \mathrm{Cal} .118,120,55$ Pac. 798 (1898) (where the court assumes that the statutory right to redeem is applicable); Brown v. Kahn, 176 Cal. 159, 164, 167 Pac. 869, 872 (1917).

177 CAX. Crv. CoDE $\S \S 2924 a, 2924 b$. 
And he should bear in mind that even a judicial foreclosure of a power of sale mortgage or deed of trust would result in only a three-month redemptive period following the sale. ${ }^{178}$

\section{Restitution}

Never will the vendor be forced to make restitution; he can avoid it by insisting upon a judicial sale, but here again he is strugghing to approach the advantages he would have had under the deed of trust or mortgage. ${ }^{170}$ Assume a case of an individual seller choosing a land contract for secondary financing in the sale of his former residence. The buyer adds $\$ 5,000$ in inprovements, the buyer's payments under the three-year contract exceed rental value, and the value of the property appreciates at about the inarket rate of the last few years. The buyer is in default and the seller wants to enforce his security. Because Freedman gives the buyer the right to restitution whether or not the seller sues to quiet title and regardless of the buyer's fault, the seller is faced with either attracting sufficient cash to reimburse the buyer for improvements and excess of paynents over rental value or insisting upon a judicial sale. The latter alternative, in view of the litigation involved, the inordinantly long redemption period during which the buyer remains in possession, and the possibility of the vendor's having to bid in himself and thereby make the payments on the senior encumbrance during the year of redemption, is certainly not attractive to the seller. On the other hand, if he cannot raise the money to make restitution he has no real choice. ${ }^{180}$ For that matter, what choice he has, in view of Ward's "choice-to-the-vendee" approach, is limited to acquiescing in the vendee's request for restitution or insisting upon a sale. It is likely, unless the vendee prefers restitution, that the vendee will convert any affinnative relief other than a sale to a sale.

In any event, it is in the restitution area alone that the measure of the installment vendor's damages is important. The anti-deficiency legislation moots the damages question for all purposes other than deciding how much the vendor must return, a question upon which the defaulting vendee has the theoretical burden of proof. ${ }^{181}$ Although there is considerable loose

178 To cut the one-year period to three months after action and judicial sale under his power of sale instrument, he would have to bid in for the amount of his ben. CAL. CoDE Crv. Proc. 8 725. But since we are comparing purchase money instruments upon which he cannot have a deficiency judgment, CAL. CODE Crv. Proc. $\$ 580 \mathrm{~b}$, it may be assumed that he will do so.

$179 \mathrm{He}$ will never get there, though, because the vendor does not have a power of sale and is faced at least with hitigation, and his sale is followed by a more oppressive redemption than would be the case under a mortgage.

180 Avoiding this dilemma is the theme, in the individual vendor context, of Rudolph's analysis. Rudolph, The Installment Land Contract as a Junior Security, 54 Micr. L. Rev. 929 (1956), see note 142 supra.

181 See, e.g., Freedman v. The Rector, 37 Cal. 2d 16, 230 P.2d 629 (1951). 
authority to the effect that the measure of damage under the imstallment contract is difference value, ${ }^{182}$ the measure probably is rental value ${ }^{183}$ unless it is converted to a forced difference value by judicial sale. In addition to rental value, the vendor is entitled to expenses incurred in enforcing the security to the extent reserved by contract; ${ }^{181}$ but under a clear security instrument, the expenses of sale ${ }^{185}$ and increase or decrease in value are irrelevant.

To round out the picture, perhaps a quick look at what remains of the vendor's affirmative remedies will demonstrate that it is nonsense to continue to call the land contract the California vendor's preferred security device, as sonie still do. ${ }^{186}$

\section{B. Vendor's Affirmative Remedies}

\section{Effect of Anti-Deficiency Legislation}

Because Code of Civil Procedure section 580b prohibits a deficiency judgment under the installment land contract, the existence of any meaningful remedy for the vendor depends upon his somehow avoiding it. Several avoidance possibilities have been suggested; none of them will work.

A good technical argument can be made, for example, that the creditor can have the debtor waive section $580 \mathrm{~b}$ at the time of the contract. The argument is that the legislature, in prohibiting the advance waiver of various sections including section $580 \mathrm{a},{ }^{187}$ did not prohibit the waiver of section $580 \mathrm{~b}$ and it is, therefore, not of sufficient public interest to be nonwaivable. Beside the obvious difficulty that if they worked, advance waivers would soon become "boiler-plate" in every security device and section 580b then would be meaningless, the supreme court seems to have gone out of its way to warn that it considers section 580b non-waivable ${ }^{188}$ even though there is, as yet, no clear holding to that effect.

182 Pursuant to $\S 330 \%$. This sort of thing reaches back to Glock, continues occasionally through the modern cases, and is sometimes still repeated in the law reviews, e.g., 10 STAN. L. REv. 355 (1958); 7 U.C.L.A.L. REv. 83 (1960).

183 See, e.g., Ward v. Union Bond \& Trust Co., 243 F.2d 476 (9th Cir. 1957) ; Bird v. Kenworthy, 43 Cal. 2d 656, 277 P.2d 1 (1954) (personal property, but same measure); Heintzsch v. LaFrance, 3 Cal. 2d 180, 44 P.2d 358 (1935); Roberts v. Lebrain, 113 CaI. App. 2d 712, 248 P.2đ 810 (1952); Nelson v. Dangerfield, 125 Cal. App. 2d 146, 269 P.2d 953 (1954).

184 Tibbets v. Robb, 158 Cal. App. 2d 330, 322 P.2d 585 (1958). The main expense usually is attorney's fees.

185 The broker's commission is the primary expense.

186 The statenient was true in 1939, see Note, 27 CAITF. L. REv. 583 (1939), but it is still often repeated in the cases, and, imcredibly, a current note purporting to compare the mortgage, deed of trust and land contract reached the same conclusion. See Note, 7 U.C.L.A.L. Rev. 83 (1960). The note seemed to draw mainly upon Ogden, Cactrorna Reat Property (1956) and several of the early law review articles, all of which are, of course, badly out of date.

187 CaI. Crv. Code $\S 2953$.

188 Freedland v. Greco, 45 Cal. 2d 462, 289 P.2d 463 (1955). See also Lucky Investunents, Inc. v. Adams, 183 A.C.A. 463, 7 Cal. Rptr. 57 (1960). 
Attempting to avoid section $580 \mathrm{~b}$ by avoiding a judicial sale is also futile. As pointed out earlier, ${ }^{189}$ the land contract and deed of trust (or mortgage) are equatable only where Code of Civil Procedure section 726 no longer prevents a direct action independent of the security under the latter instruments. And in sucli a case the court held that a deficiency judgment is any personal judgment against the debtor-only the land can answer for the debt-and the existence of a judicial sale is irrelevant. ${ }^{100}$ Thus, benefit of the bargain damages, damages based upon rental value, in fact any relief on the contract other than tort or other unrelated damages, ${ }^{191}$ probably will be barred by section $580 \mathrm{~b}$.

Another common suggestion ${ }^{102}$ is that the vendor tender a deed, obtain a judgment for the price and then levy upon the property to satisfy the judgment, retaining a judgment for whatever the property does not satisfy. To do this, the vendor must first get a judgment for the price and a decree passing title without the decree itself calling for a judicial sale if the vendee does not pay. This alone seems an insurmountable barrier. ${ }^{193}$ Even if he does so, lowever, he must then convince the court that an execution sale to enforce a judgment for the price is not "any sale" for failure of the purchaser to complete his contract of sale. And, finally, to convince the court that he should get a judgment in this form notwithstanding Brown v. Jensen, he must have a court that would condone a patent evasion of section $580 \mathrm{~b}$ for the vendor's benefit. And it would be difficult, if not impossible, to find this attitude anywhere in the California judiciary.

Given a security instrument, section $580 \mathrm{~b}$ applies. ${ }^{104}$

\section{Cancellation; Private Enforcement}

Private enforcement of the contract by cancellation and forfeiture is generally considered to be the vendor's best remedy. ${ }^{105}$ If it still worked, it would be. It is true, of course, that the vendee may acquiesce ${ }^{100}$ - he may move off, he may not cloud the title, he may execute a quitclaim, he may not sue for restitution, he may just give up on the whole thing-but this does not mean the vendor can count on the remedy by acquiescence. It is

189 See notes 103-07 supra.

190 Brown v. Jensen, 41 Cal. 2d 193, 259 P.2d 425 (1953) ; Jeanese, Inc. v. Surety Title \& Guarantee Co., 176 A.C.A. 4, 1 Cal. Rptr. 752 (1959).

101 Cf. Garrett v. Perry, 53 Cal. 2d 178, 346 P.2d 758 (1959).

${ }^{192}$ See, e.g., Howell and Russell, Legislation, 9 So. Cax. L. Ruv. 335, 355 (1936) ; Comment, 7 U.C.L.A.L. REv. 83, 99 (1960).

183 See notes 88-93 supra and accompanying text. Although a decree in this form was used in two cases there described, both were marketing rather than security cases.

194 See also Riesenfeld, California Legislation Curbing Deficiency Judgments, supra at 705. 195 See, e.g., the law review articles cited in note 9 supra. See also OCDEN, Carrfornia REAL PRoperTy ch. 9 (1956), and Comment, 7 U.C.L.A.L. REV. 83 (1960).

196 This seemingly is why it is considered still his best remedy in Comment, 7 U.C.L.A. L. REv. 83 (1960). 
equally true that a mortgagor or trustor by later contract may give up his equity of redemption, ${ }^{197}$ but certainly no one seriously argues that this possibility makes private strict foreclosure a good remedy for the mortgagee or beneficiary. The point is that the vendee no longer can be compelled to acquiesce and thus private strict foreclosure is no longer one of the vendor's remedies. Consider some of the difficulties he might expect with private enforcement.

First, he must regain possession. Perhaps he can coerce the vendee into giving it to him. Perhaps the trial court will enforce the fairly common contract provision changing the contract into a lease upon default and make unlawful detainer available. But judging by the reported cases im California, the vendor runs a substantial risk of having to resort to nuajor hitigation to eject the vende $e^{188}$ and considering expense and calendar delay, there really is little to choose between this remedy and the inexpensive "repossession" offered by the power of sale under the other security devices.

After he has regained possession, the vendor still has problenis. The vendee, even if his breach was willful, has the right to have the contract reinstated or specifically enforced. ${ }^{198}$ So he may start an action, file a notice of lis pendens and effectively present a resale. Or he may simply cloud the title. ${ }^{200}$ Again the choice between a quiet title action and the power of sale procedure is obvious.

Even if the vendor has both possession and a quiet title, the burden of making restitution remains. Actually, restitution will most commonly be necessary as a prerequisite to the vendor's relief in a quiet title or ejectment action. But overlooking this, the vendee may bring an action for restitution on his own whether or not his breach was willful. ${ }^{201}$ This can be a serious risk to the vendor.

Assume, for example, that the vendor has retaken possession by summary proceedings, his record title is quiet and he has resold the property to a bona fide purchaser on another long-term, narrow-nlargin contract. The sale to a bona fide purchaser will avoid the possibility that the first vendee may encumber the title- he is too late to have specific performance $^{202}$ - but it also prevents the vendor from choosing to avoid restitution

197 As he can in California. See, e.g., Watson v. Edwards, $105 \mathrm{Cal} .70,38$ Pac. 527 (1894); De Martin v. Phelan, 115 Cal. 538, 47 Pac. 356 (1897).

198 Picking at random, see, e.g., Tibbets v. Robb, 158 Cal. App. 2d 330, 322 P.2d 585 (1958); Cupps v. Henđricks, 137 Cal. App. 2đ 211, 289 P.2đ 810 (1955); Roberts v. Lebrain, 113 Cal. App. 2d 712, 248 P.2d 810 (1952).

199 Ward v. Union Bond \& Trust Co., 243 F.2d 476 (9th Cir. 1957).

200 Which is not at all difficult even with the unacknowledged contract. See notes 71-75 suspra and acconpanying text.

201 Freedman v. The Rector, 37 Cal.2d 16, 230 P.2d 629 (1951).

202 In fact this may have been the only reason the willful defaulter did not get it in Freedman. 
by a judicial sale. If the vendor, as may be typical of the individual seller, no longer has the funds with which to make restitution and if his new contract is extremely close financing, as again may be typical, his only marketable asset with which to raise the money to satisfy the restitution judgment is the contract. And discounting a close contract will unquestionably result in a considerable loss. Again, he could have avoided the problem by a sale under the power-he would then either have taken out his interest in cash $^{203}$ or bid in for the amount of his hen, avoiding under the latter alternative any question of restitution while still being in a position to offer for sale a quiet title within three and one-half montls of the default.

\section{Damages, Action for the Price, Specific Performance}

In two recent cases ${ }^{204}$ the vendor recovered substantial damages from the defaulting vendee and in neither case was the anti-cleficiency section urged as a defense. The cases could be dismissed simply as examples of cases in which the litigants failed to raise a valid defense and the court was misled thereby. But it is possible that the parties or the court considered and rejected Code of Civil Procedure section 580b upon the theory that the vendor's position was similar to that of a mortgagor who remains in possession during the year of redemption and is liable for the value of his occupation, section $580 \mathrm{~b}$ notwithstanding. ${ }^{205}$ Or it is possible that the court based the vendor's right to damages upon the theory that the vendor was entitled to possession immediately following the vendee's breach and was entitled, therefore, to all payments accruing thereafter as damages for unlawful detention. The first possibility seems to be an inaccurate analogy; the second seems to beg the question.

Instead of being in the position of a mortgagor during the redemption period, the vendee seems to occupy a position similar to that of a mortgagor who fails to make payments on his second mortgage but remains in possession prior to foreclosure. If the first mortgagee later exhausts the security, the second mortgagee has no remedy; he is no longer: secured and he cannot recover any part of the indebtedness from the mortgagor. ${ }^{208}$ The apparently significant difference between this and the land contract situation is that the vendor generally is entitled to immediate possession upon default by the terms of the contract whereas the second mortgagee would never become entitled to possession (assuming exhaustion of the security by a prior lien). But the vendor must establish his right to possession by judicial action and damages accruing prior to the action are the same as those that

203 From a third party bidder.

${ }^{204}$ Luz v. Lopes, 182 A.C.A. 835,6 Cal. Rptr. 412 (1960); Maloney v. White, 182 A.C.A. 900, 6 Cal. Rptr. 540 (1960).

205 CAL. CODE Crv. Proc. \$ 707; Carpenter v. Hamilton, 24 Cal. 2d 95, 147 P.2d 563 (1944).

206 Brown v. Jensen, 41 Cal. 2d 193, 259 P.2d 425 (1953). 
seemingly would accrue after breach but before foreclosure (or sale under the power) under a mortgage. Certainly the economic effect is the same in both cases. And if section $580 \mathrm{~b}$ does not prevent a personal judgment against the vendee for past rental value, it has no application to the installment contract except in those cases where there is a judicial sale because damages under the installment contract always are measured by rental value. ${ }^{207}$ The result, of course, would be that in practically no case would section $580 \mathrm{~b}$ apply to a judgment against the vendee, even though section $580 \mathrm{~b}$ expressly purports to prevent a personal judgment against the vendee as a result of his failure to complete his contract of sale. If a judicial sale is not a prerequisite to a deficiency judgment after default under a mortgage or deed of trust, ${ }^{208}$ certainly it is not a prerequisite under the land contract. The supreme court seems clear in its holding that with any purchase money security device the creditor is limited to his security for satisfaction of the debt. ${ }^{200}$

Thus, it seems that any vendee inclined to raise section $580 \mathrm{~b}$ has a complete defense to any action for damages based upon his default. Collateral damages, those based upon fraud, for example, are possible of course, ${ }^{210}$ but they have no relation to the deficiency problem that arises when the vendor seeks damages on the contract.

The anti-deficiency section also prevents a meaningful action for specific performance. While specific performance is available, the result of the action would be an alternative decree under which the property would be sold by judicial sale if the vendee were unwilling or unable to pay the price. There can be, of course, no deficiency judgment following the judicial sale. Thus, it seems highly unlikely that a vendor would choose specific performance in preference to a quiet title action followed by a more profitable nonjudicial resale. Forcing the vendor to this choice, however, deprives him of specific performance as a remedy by indirection.

\section{Present Status of the Installment Contract as a Security Device}

Destruction by indirection is really the whole story of the installment land contract in California. Some states have done it by legislation, ${ }^{211}$ but

207 See note 183 supra.

208 Brown v. Jensen, suspa note 206.

200 Ibid. See also Jeanese, Inc. v. Surety Title \& Guar. Co., 176 A.C.A. 4, 1 Cal. Rptr. 752 (1959) ; compare notes 103-07 supra and accompanying test.

210 Cf. Garrett v. Perry, 53 Cal. 2d 178, 346 P.2d 758 (1959).

211 Maryland provides the most complete recent example. There a purchase money mortgage must be given after a certain percent of the contract has heen paid. But the vendor's rights are increased upon taking the mortgage, leading obviously to his preference for a mortgage in the first place. See Howe, Forfeiture in Land Contracts, in CuRrent Treands IN State LEGISLATION 417 (1953-54). On the other hand, some states-Michigan is a good examplegive legislative impetus to the contract by providing effective summary enforcement. See Waalkes, Land Contracts: A Mongrel Breed, 37 MicH. S.B.J. 10 (1958). 
California's judiciary destroyed it by gradually changing the remedies in different contexts until suddenly there was nothing left. The result of each case going into the process seemed commendable and, indeed, each individual case was praised by the law review commentators. Perliaps the supreme court has had the total picture in mind for years; perhaps it specifically intended from the time of Barkis to destroy the contract as a security device. Whether or not it should have depends largely upon one's philosopliy -but with liberal nonjudicial enforcement under the other devices, the question, regardless of philosophy, is not as important in California as it would be in most other jurisdictions.

A short summary of the position of the land contract: today is that it offers far more disadvantages than advantages to both buyer and seller. Its disadvantages to one are not offset by commensurate advantages to the other.

Limiting the choice to a power of sale mortgage or a deed of trust on the one hand and an installment land contract on the other, the disadvantages of the contract to the vendor include the time and expense of quieting title and of regaining possession by action and the possibility of having to make restitution, an additional investment in possibly overencumbered property. The quick, certain and relatively inexpensive solution of these problems by a sale under the power leaves little to recommend the contract. The contract, moreover, offers no deficiency judgment adyantage over the purchase nroney mortgage or deed of trust-the judgment is not proper under any instrument.

The disadvantages to the buyer are equally discouraging. The transfer of his interest frequently is restricted by covenants against assignment. Obsolete, or perhaps overly conservative, opinion among lenders that his interest is subject to more rapid termination upon default makes his interest poor collateral if he needs security to raise additional money. Upon completion of his payments under an installment contract, a purchaser faces the possibility of receiving either a defective title or no title whatever. ${ }^{219}$ And if the vendor is adjudicated bankrupt, if title has passed to the vendor's heirs or if the vendor is under a legal disability, the purchaser can look forward to frustrating litigation before obtaining his deed upon completion of his payments.

Despite all of this, it would be naive to assume that the contract is not still the preferable device to some. Thus, abstract comparison of the advantages and disadvantages of the contract overlooks, again, people. Undeniably the land contract renrains attractive to several of the large devel-

212 The contract commonly will call for a good (i.e, insurable) title only upon buyar's completion of his obligation. The vendor need not have a good title prior to the time when he is to convey and the purchaser has no defense for his own nonperformance based upon the vendor's lack of title during the pendency of the contract. 
opers because the low (in comparison to rental value) installment payments make it unlikely that the defaulting purchaser will do anything other than leave the property, with suffient prodding, thus making it again available for sale without litigation or even an extrajudicial sale. In other words, the risk of an occasional clouded title or of an occasional ejectment action is inore than offset by the advantages of old-fashioned private enforcement which, while theoretically barred, remains an excellent remedy against an uninformed purchaser. And undoubtedly the land contract offers far greater opportunity for unconscionable manipulation by those so inclined. But from the standpoint of the individual seller offering secondary financing on his former home, the contract generally would be a poor choice. He does not have volume savings to compensate for hitigation expense, and often he is financially unable to choose a security device which carries with it the risk of subjecting him to considerable future expense.

It is important to the lawyer advising the individual seller to know that the notion that the land contract is the seller's most favorable security device is simply no longer true, just as it is important for the lawyer advising the developer or builder to be aware of the extent of the risk involved in preferring the land contract. And certainly anyone representing a buyer, either at the litigation or contracting stages, must be aware of all of the remedies and defenses available. It is imexcusable to continue to find cases in which the debtor fails to raise section $580 \mathrm{~b}$ or fails to show the requisites for restitution.

Thus, though some may choose to use it after thoughtful consideration of the possibilities, it is nevertheless important to know, and to know why, the land contract is legally obsolete as a security device in California. 